\title{
https://journal.oiu.edu.sd/index.php/oiuj
}

\section{فقه الدعوة هن خلال المرحلة المكية}

/ إبر اهيم علي مصطفى "

\section{مستخلص البحث}

الحمد لله و أصلي على رسوله الكريم صلى الله عليه وسلم ولقد كان من

نعم اله تعالى أن أكمل هذا البحث وهو بعنوان: فقه الدعوة من خلال المرحلة المكية. ولقد قسمته إلى مباحث، ومن خلال هذا البحث أرى أن أن هنالك مشاكل

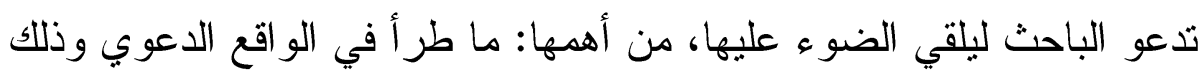

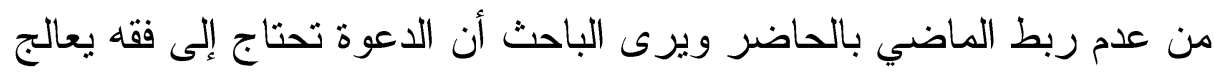
الو اقع اليوم، و لابد من الرجوع ربط إلى فقه الدعوة في العهد المكي.

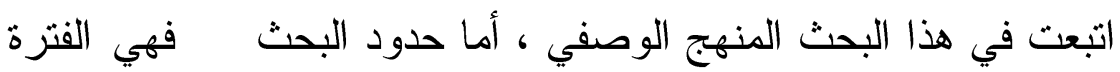

المكية من بداية الدعوة وحتى هجرة رسول اله صلى الله عليه وسلم إلى المدينة

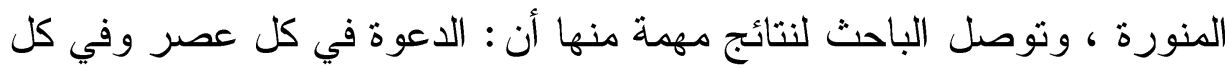

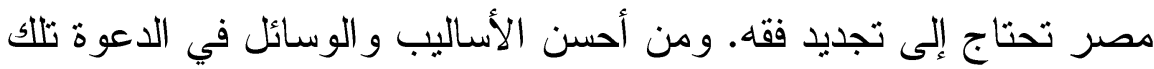

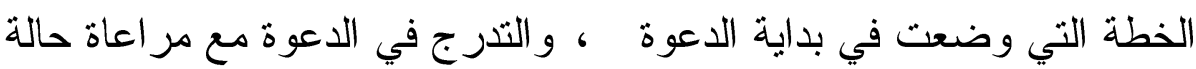

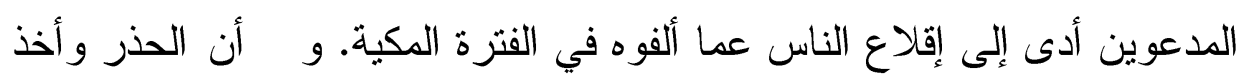

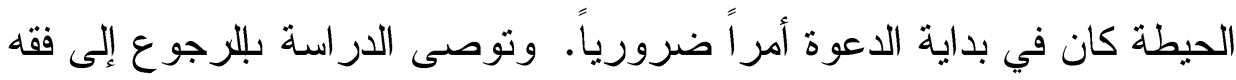

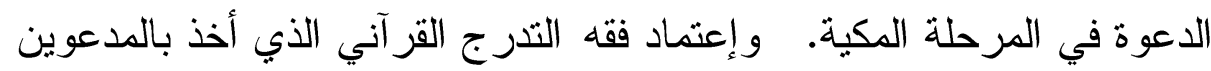

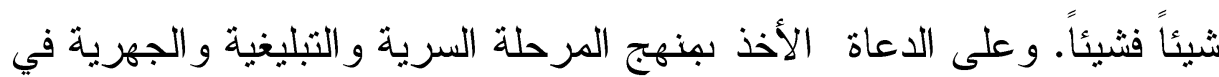

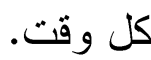




\section{Abstract:}

Praise be to Allah and His considerate Prophet (Peace and Blessing of Allah be upon Him), Allah bestowed me to complete this study entitled: "Jurisprudence of Dawa "Islamic Call" through the Meccan Stage". The study has been divided into enquiries, through this study, the researcher finds out that there are problems need to shed light on them, the most important of which are: the new events in reality of Dawaa "Islamic Call" which is are due to separation of the past from the present. The problem of this study lies in the fact that the Dawa "Islamic Call" requires jurisprudence 'Fiqh' that accompanies today' situation, it is prerequite to return to jurisprudence of Dawa "Islamic Call" in Meccan era.

The study employed the descriptive, method, the limits are represented in the Meccan Stage, before the emigration of Prophet Mohamed (Peace and Blessing of Allah be upon Him) to the holy madina.

The study achieved many important results: the Dawa "Islamic Call" requires a good knowledge of jurisprudence. The sequence of Dawa "Islamic Call" with callers leads people to refrain from their interest in the Meccan Stage. Carefulness and caution practiced in mecca at the beginning of Dawaa "Islamic Cal" is necessary even today. The study concludes with number of recommendations. The most important are: it is necessary to return to Quranic sequence that take the callers gradually. The Dawa scholars should follow the secret, informative and obvious stage throughout the time. 
المقدمة:

الحمد لله الذي قدر الزمان و المكان ونصلي على رسول اله صلى الله عليه وسلم نبي الزمان و المكان، ثم نحمد الله تعالى أن جعل لنان النا مكة مكاناً

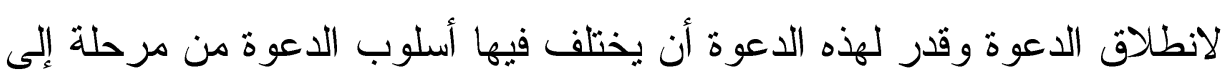

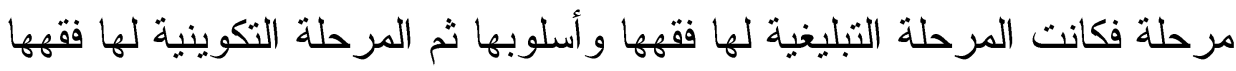
وأسلوبها ثم المرحلة الجهرية لها فقهها و أسلوبها.

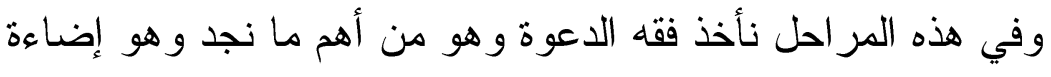

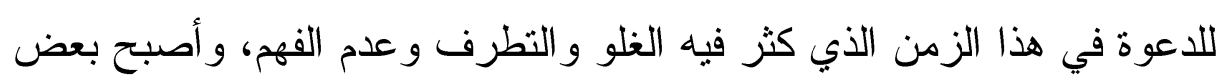

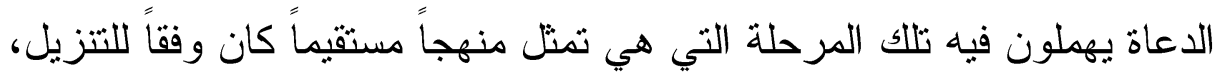

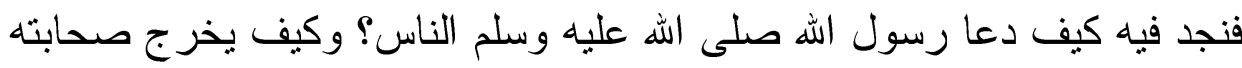
من مأزق الكفار آنذالك و هم قلة؟ وكيف كان يؤدي عبادته وهو في الخفاء؟ ثم الثم نجد أن الصحابة الكر ام رضي اله عنهم، كانو ال اليستجيبون لاستفز از الكفار

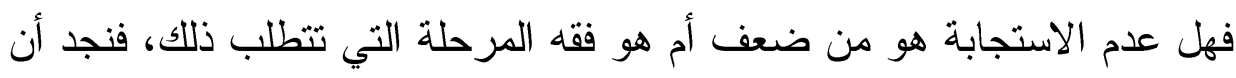

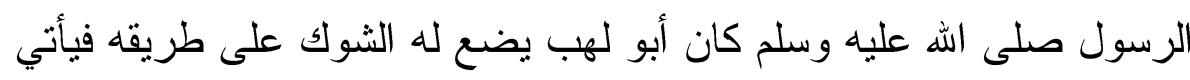

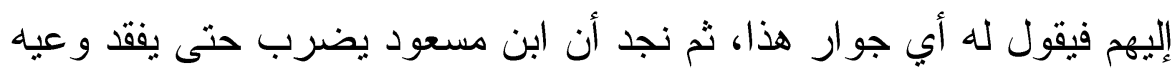

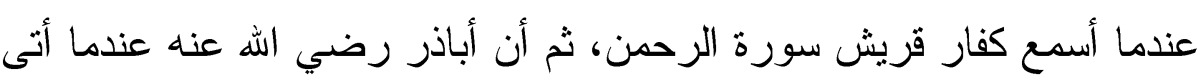

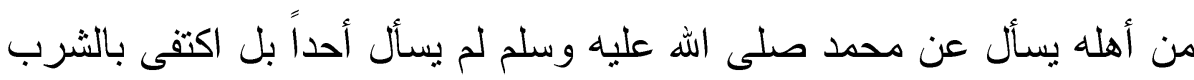

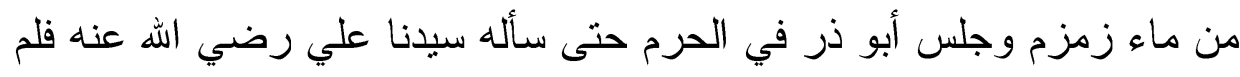

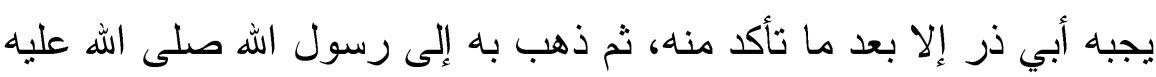

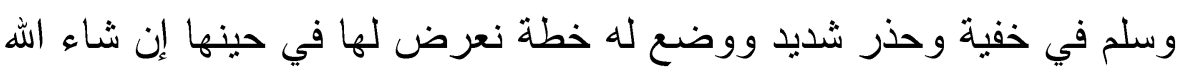

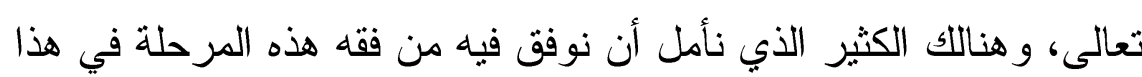

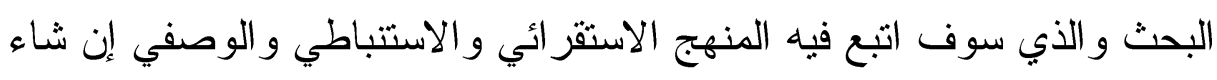
الله تعالى. وذللك كما نجد في الفصل الأول وهو المفهوم العام لفقه الدعوة. 
مشكلة البحث:

تكمن مشكلة البحث في عدم ربط الدعاء بماضي الدعوة بو اقع اليوم، إنها،

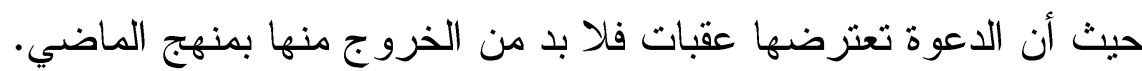

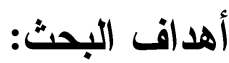

يهدف البحث إلى التعريف بقةه الدعوة وذلك عبر مر احلها المختلفة (السرية و الجهرية)، وكذللك كيفية التعامل مع و اقع الدعوة في تلك اللحظة التهات.

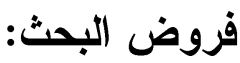

نجد هنالك عدة تساؤلات منها:

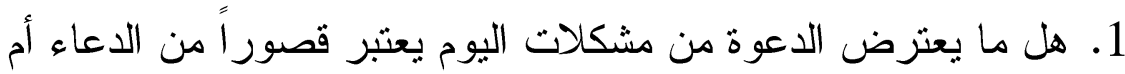

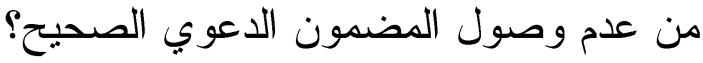

2. هل فقه الدعوة الذي كان عليه رسول الله صلى الله عليه وسلم في بداية

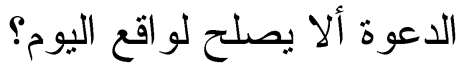

3. هل التدرج الذي سلكه رسول اله صلى الله عليه وسلم في بداية الدعوة

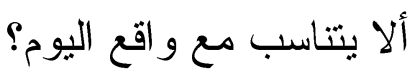

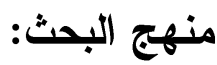

اتبع الباحث المنهج القائم على الاستقر اء و الاستتباط .

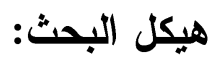

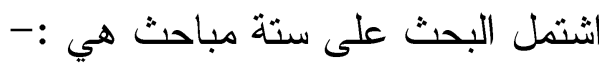

- المفهوم العام لفقه الدعوة.

- فقه الدعوة من خلام مر احلها.

- دعوة الأفر اد في المرحلة المكية.

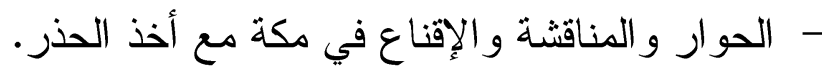

- - ميعة العقبة الأولى و الثانية.

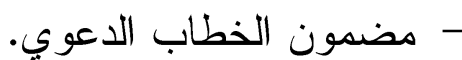

بالاضافة إلى مقدمة منهجية وقائمة تضمنت نتائج البحث وتوصياته. 


\section{المبحث الأول \\ المفهوم العام لفقه الاعوة}

الاعوة لغة واصطلاحاً:

الدعوة لغة هي الطلب و اصطلاحاً هي تبليغ الناس بالإسلام وتعليمهر واصطان إياه وتطبيقه في و اقع حياتهم.

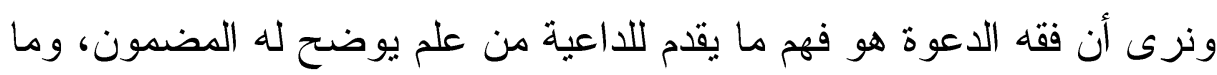

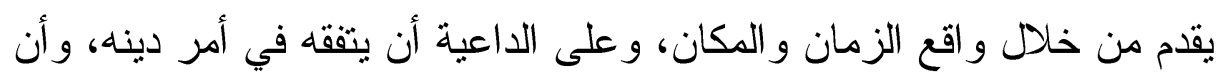

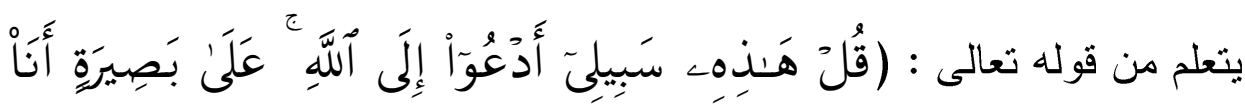

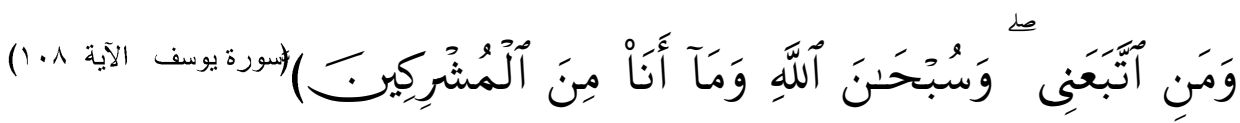
الأمر الذي سيلغه للناس، لأن البصيرة تعني المعرفة والجهل يترتب عليه

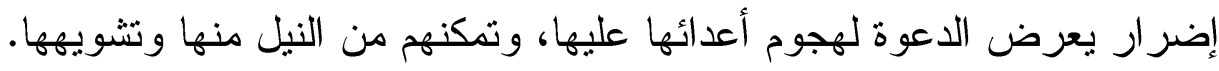

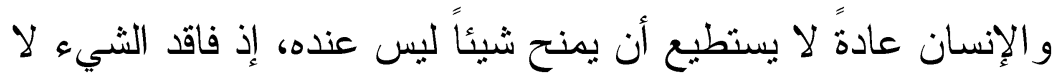

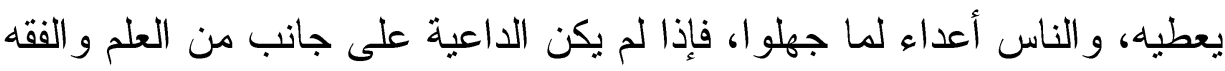

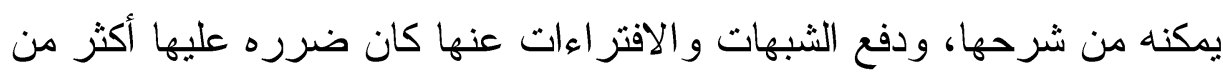
نفعه.

ونرى أن الطفيل بن عمرو لما دخل الإسلام في قلبه تبع رسول اله

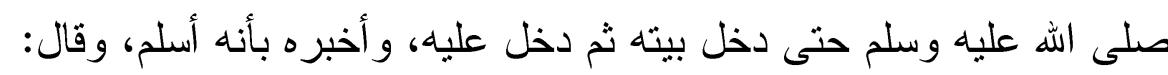

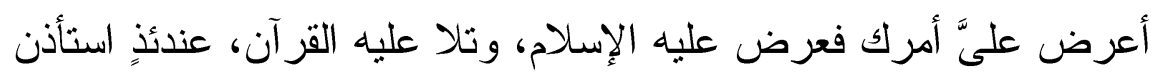

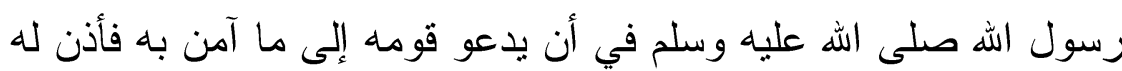

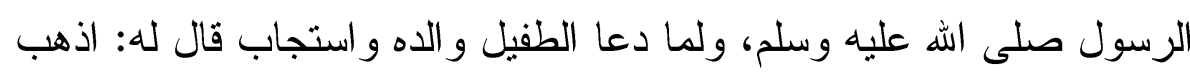

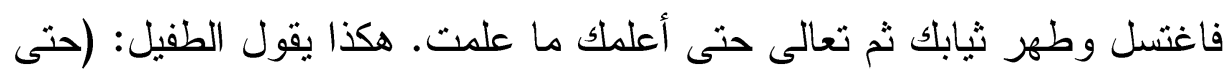

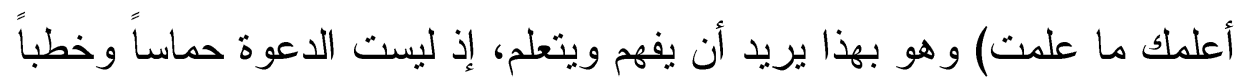

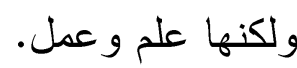


و أما ضمام بن ثُعلبه فإنه عندما وفد على رسول الله صلى اله عليه

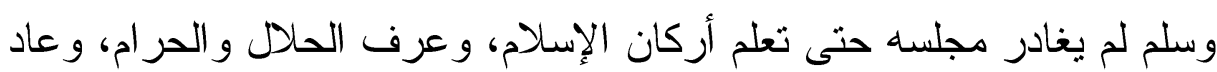

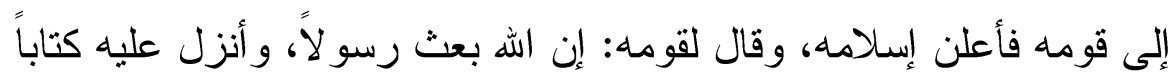

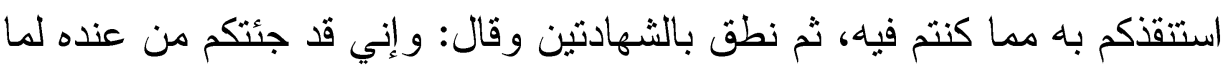
أمركم به ونهاكم عنه، وكذلك نجد من فقه الدعوة في المبحث الأول(1). 


\section{المبحث الثاني \\ فقه الاعوة من خلال مراحلها}

أولاً: المرحلة التبليغية:

بدأت هذه الدعوة عندما أتى البلاغ إلى رسول الله صلى الله علبه وسلم

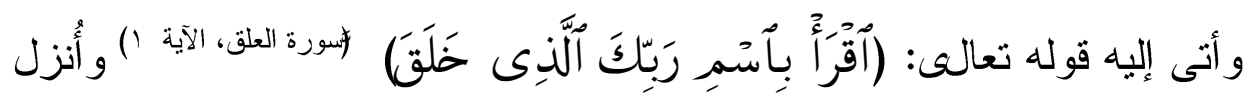

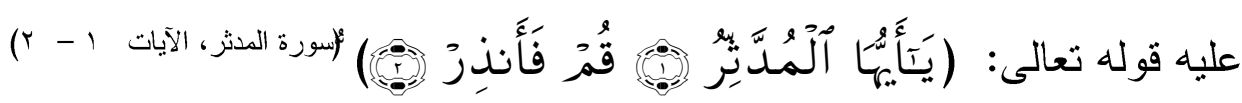
حيث قام رسول الله صلى الله عليه وسلم بالدعوة إلى الله تعالى مبلغاً في سره فكان البلاغ حيث يقابل الرسول صلى الله عليه وسلم الأفر اد و الجماعات في مكة المكرمة ويدعو الناس سراً. ونلاحظ أن هذه الدعوة بدأت بأمر الرسول صل اله عليه وسلم بالقر اعة : قال

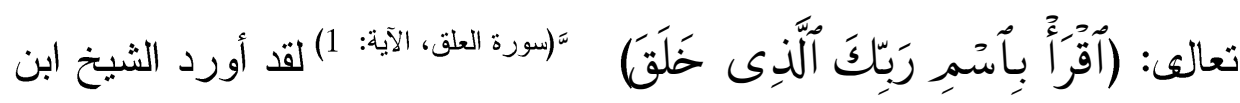
كثير حيث قال: (فأول شيء نزل من القر آن هذه الآيات الكريمات المباركات، و هن أول رحمة رحم الله بها العباد وأول نعمة أنعم الله بها عليهم، وفيها التثنية على ابتداء خلق الإنسان من علقة، وأن من كرمه تعالى أن علم الإنسان ما لم يعلم فشرفه وكرمه بالعلم وهو القدر الذي امتاز به أبو البرية آدم على الملائكة، و العلم تارة يكون في الأذهان، وتارة يكون في اللسان وتارة يكون في الكتابة بالبنان كنظري ورسمي و الرسمي يستلزمهما من غير عكس فلهذ اثقال تعالى:

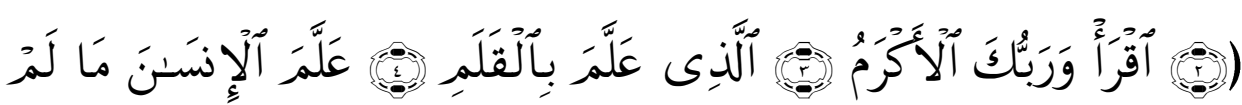

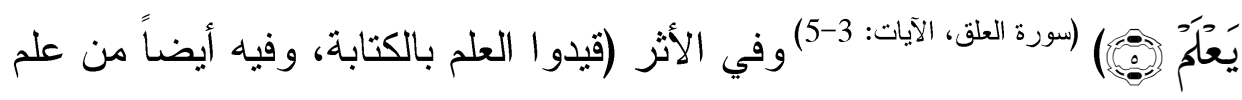
بما علم ورثه الله علم ما لم يكن يعلم)(2). ونجد أن صاحب الظلال يقول: (إنها السورة الأولى من هذا القرآن، فهي تبدأ باسم الله، وتوجه الرسول صلى الله عليه وسلم أول ما توجه، في أول 
لحظة من لحظات اتصاله بالملأ الأعلى، وفي أول خطوة من خطو اته، في

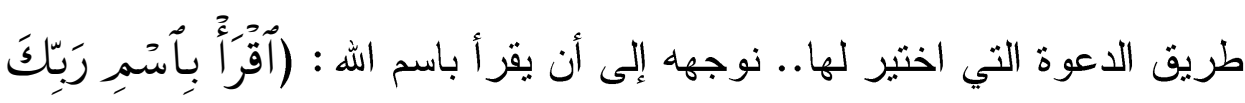
الَّلَّنِى خَلَقَ).

وتبدأ من صفات الرب بالصفة التي بها الخلق و البدء ( خَلَ) ثم تخصص خلق

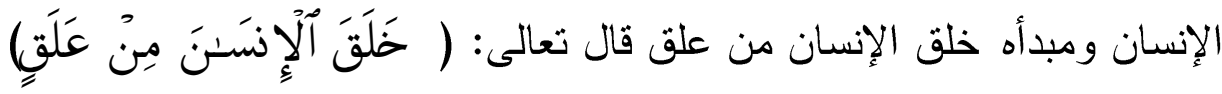
(سورة العلق، الآية: 2) من ثلك النقطة الدموية الجامدة العالقة بالرحم، من ذلك المنشأ

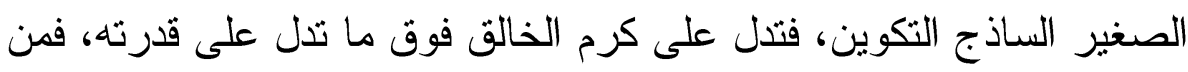

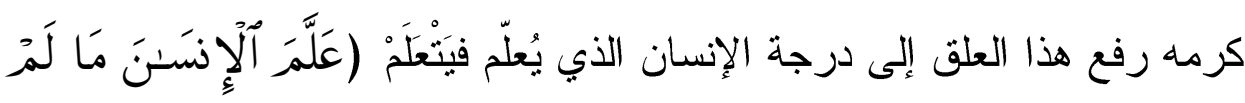
يَعَكَمَ). و إنها لنقلة بعيدة جداً بين المنشأ و المصير ، ولكن الهّ قادر ، ولكن الله كريم، ومن ثم كانت هذه النقلة التي تدير الرؤوس. و إلى جانب هذه الحقيقة تبرز حقبقة التعليم: تعليم الرب للإنسان (بالقلم)

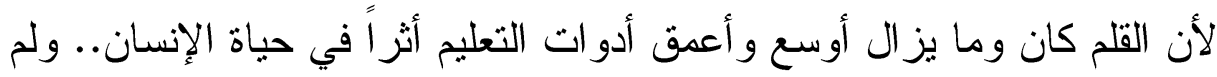

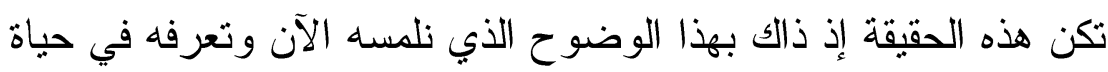

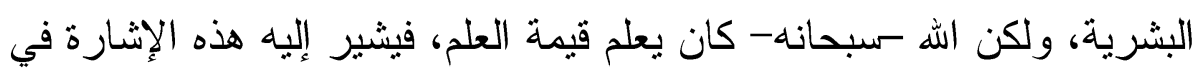

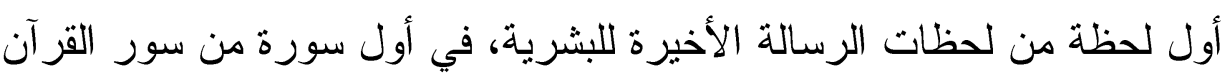

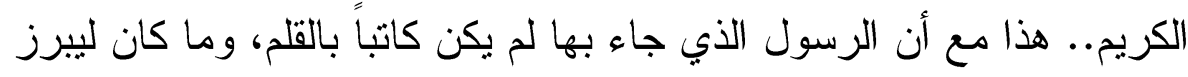

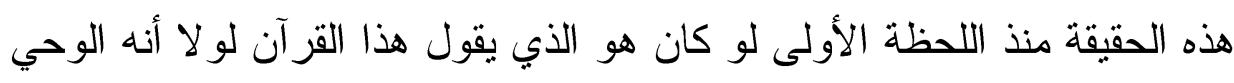
ولو لا أنها الرسالة!

ثم يبرز مصدر التعليم.. إن مصدره هو الله منه يستمد الإنسان كل ما

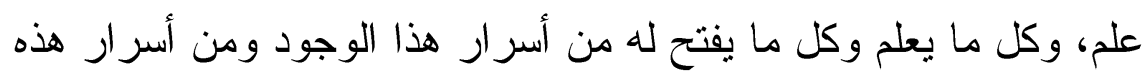

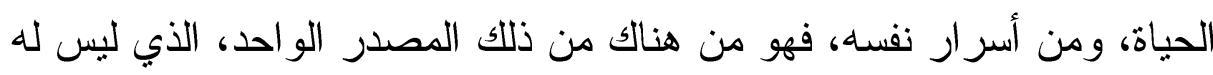


هناك سو اه، وبهذا المقطع الواحد الذي نزل في اللحظة الأولى من اتصال

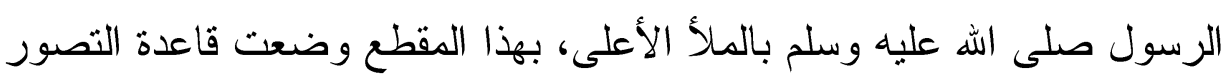
الإيماني العريضة.

كل أمر كل حركة كل خطوة كل عمل باسم الله وعلى اسم الله باسم الله

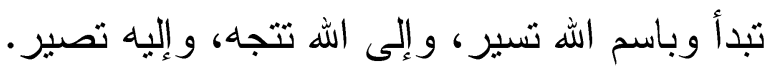

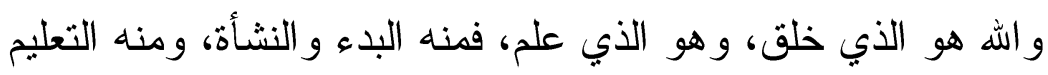

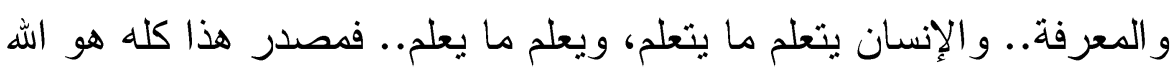

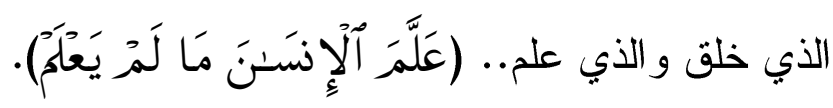

و هذه الحقيقة القر آنية الأولى، التي تلقاها قلب رسول الله صلى الله عليه

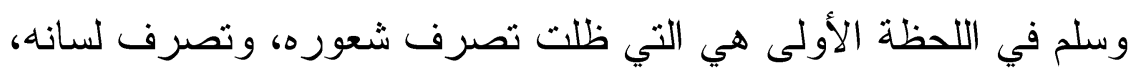
وتصرف عمله و اتجاهه، بعد ذلك طو ال حياته، بوصفها قاعدة الإيمان الأولى (3).

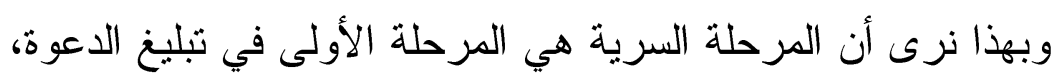

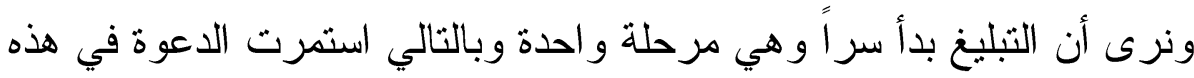

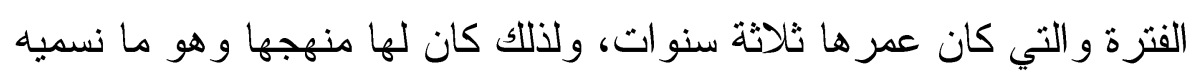
بمنهج المرحلة السرية. ثانياً: المرحلة السرية: المرحة السرية. أو لاً: في بداية هذه المرحلة هناللك تساؤلات، لماذا بدأت الدعوة سرية في

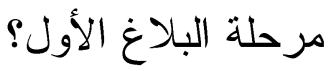

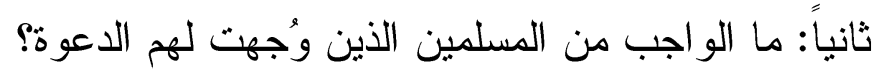

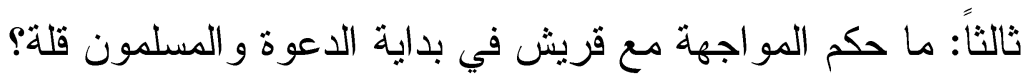

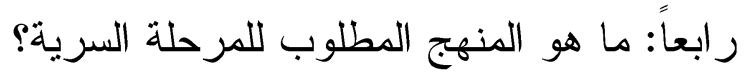

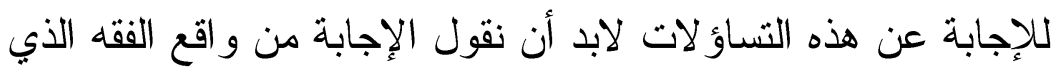
يخدم الاعوة ويعطى الإجابة الثافية. 
أو لاً: نقول أن الدعوة بدأت سرية دقيقة، الغرض منها عدم المو اجهة مع الأعداء، وتربية المسلمين تربية نظامية حتى يتعودوا ذلك منذ نشأتهم، ويكون ذللك ديدنه في حياتهم المستقبلية، والسرية هنا لا يمكن أن تكون عشو ائية،

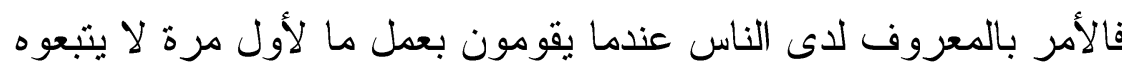

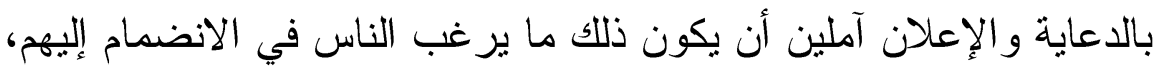

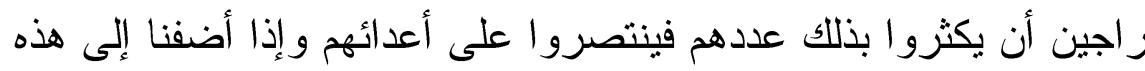

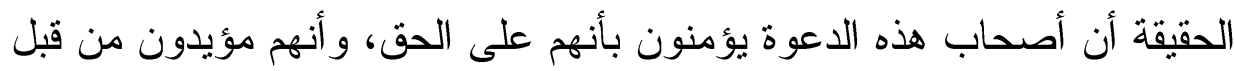
ربهم، فإن ذلك يكون من أكبر الدو افع لهم على الانتقال إلى مرحلة الدعوة بلى بلى

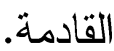

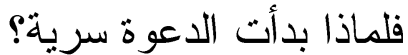

حيث يقتضي حسن التخطيط ودقة الدر اسة أن يكون منهج هذه المرحلة

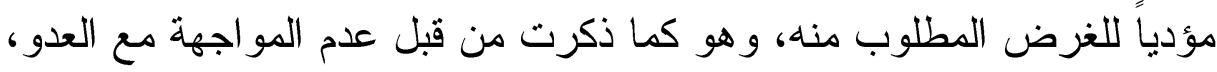
وتزبية جيل فاهم قادر على حمل التبعة والسير بها نحو غايتها، وإذا لم يؤد

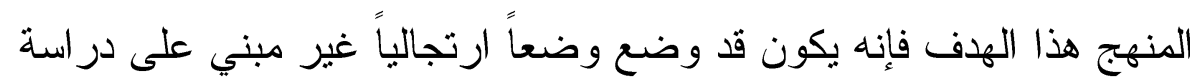
وتخطيط، وحينئذ تتعرض الدعوة للمعوقات التي تثل حركتها وتفقدها مرونتها وقدرتها على التفاعل و التأثير، وليس لهذا المعنى سوى الفشل الذي يعقبه

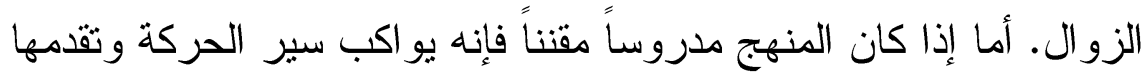

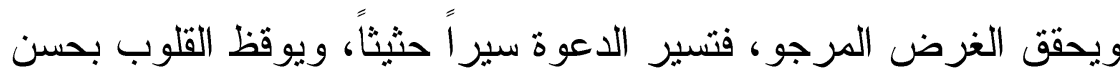
عرضها، ويتجمع الناس حولها لقوة الحق الذي تتادي به، وتسيطر على العقول بنصاعة الحق ووضوح البرهان.

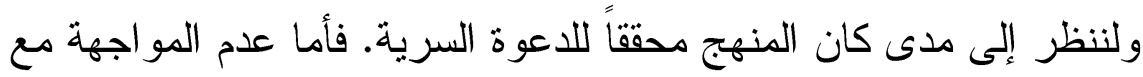

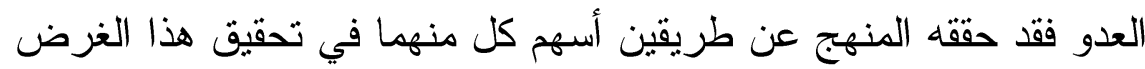

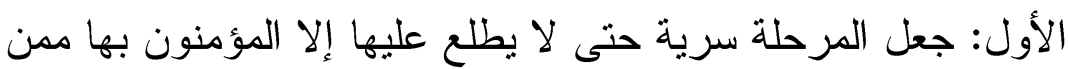
وثق فيهم رسول الله صل الله عليه وسلم وصاحبه الصديق رضى الله عنه ، وقد لإند 
ساعد ذلك على ألا تصطلم بالخصوم و المعاندين. وهؤلاء في كل أمة هم

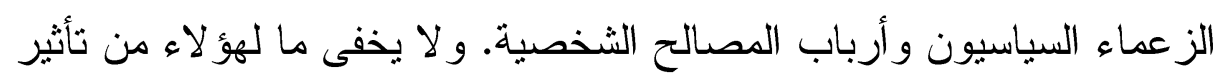
على الذين يحيطون بهم من السفلة و الضعفاء، وأنهم بحكم تسلطهم وبقوة نفوذهم يستطيعون معارضة الدعوة. وصرف الناس عنها و إيقاع الأذى بالمؤمنين بها.

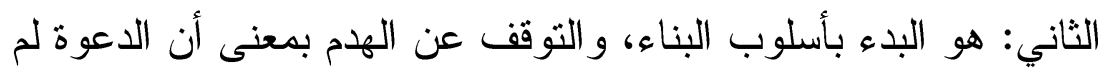

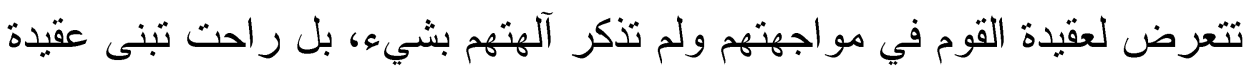

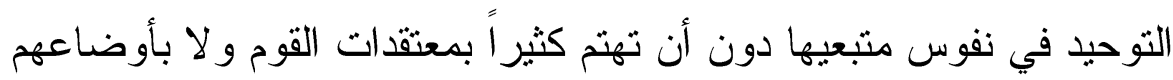
الاجنماعية، و لا غير ذلك مما يثير الغضب وبسبب الصدام.

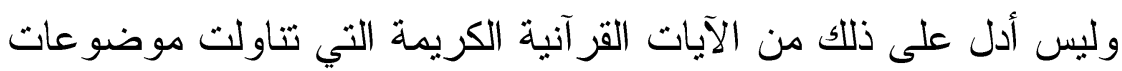

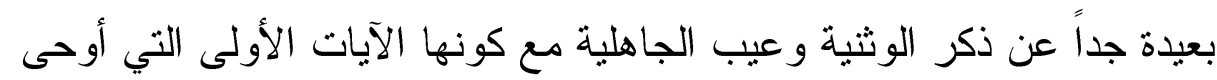

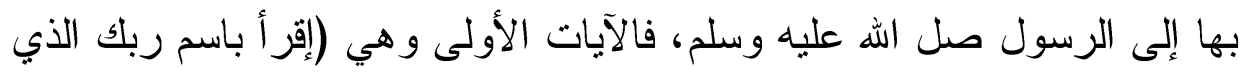

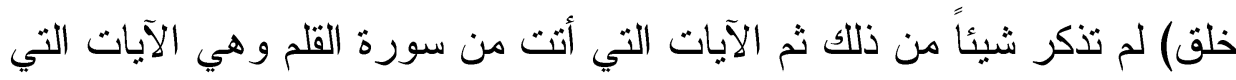

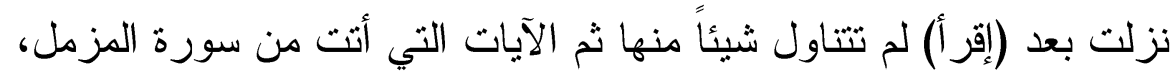

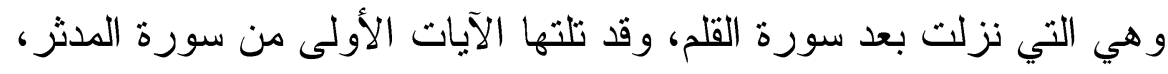

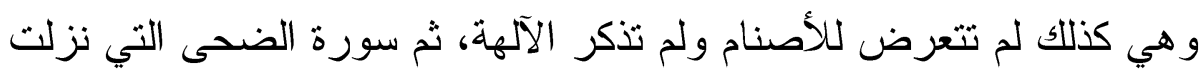

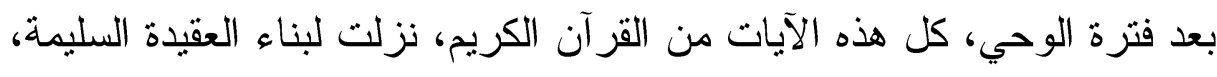

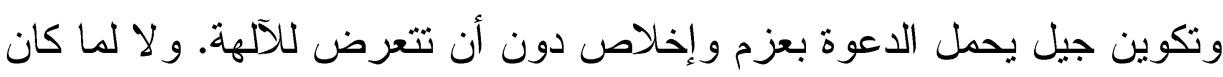
عليه المجتمع العربي من أوضاع فاسدة وخلل في التشكيل الاجتماعي و الهيكل التنظيمي.

هكذا تجنبت الدعوة الصدام مع الأعداء، وجنبت رجالها الدخول في

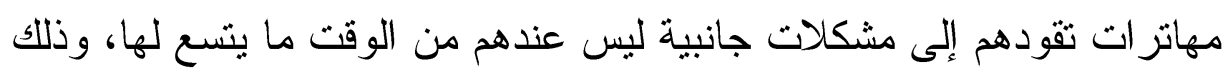

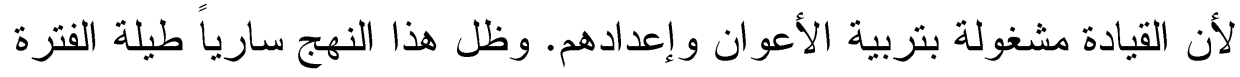
السرية، و عندما بلغ قريثاً أمر رسول الله صل الله عليه وسلم لم يكن ذللك سبياً 
في عدائهم له. وقال ابن اسحاق ولم يبعد منه قومه. ويقول المغريزي لما بلغ

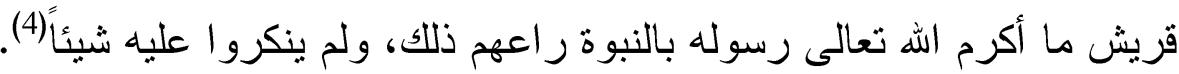

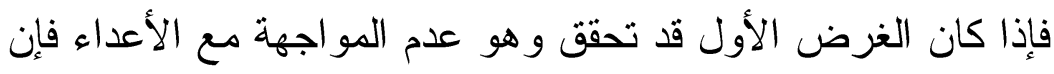

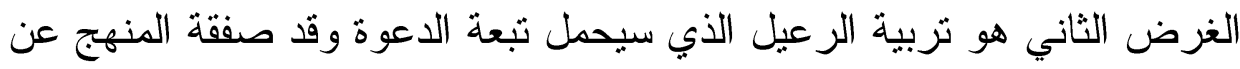

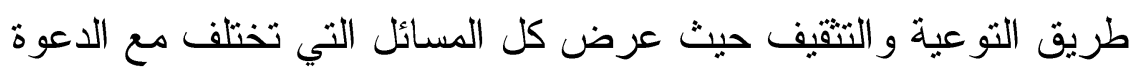
الجديدة وناقشتها بأسلوب علمي دقيق متبعاً في ذلك الطريقة الحوارية.

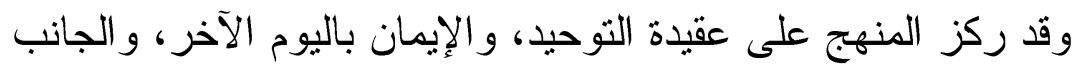
الأخلاقي، وناقش هذه الجو انب بموضوعية تامة لا يملك الإنسان السوي حيالها

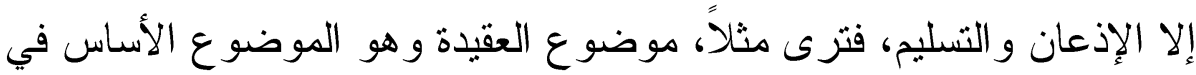

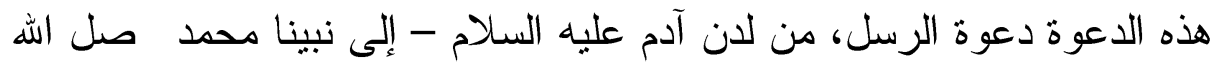

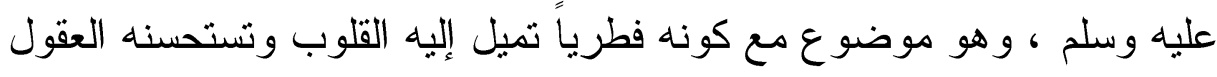

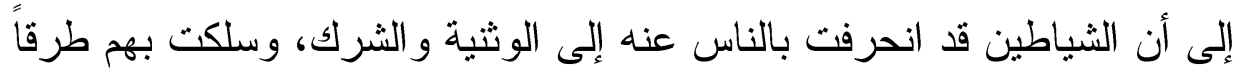
وعرة حتى ارتكبت عقولهم. ولقد تتاول القر آن الكريم هذا الموضوع بالمناقشة مع المخالفين، وعرض عليهم

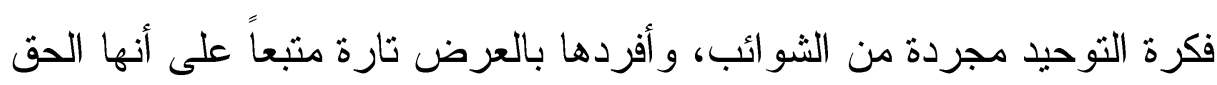

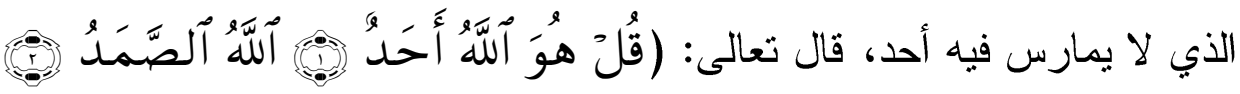

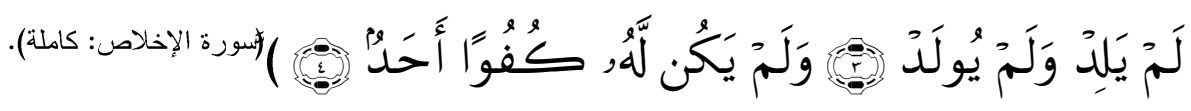

وتارة يعرضها ويعرض إلى جانبها صورة للآلهة المنتحلة ليظهر الفرق بين

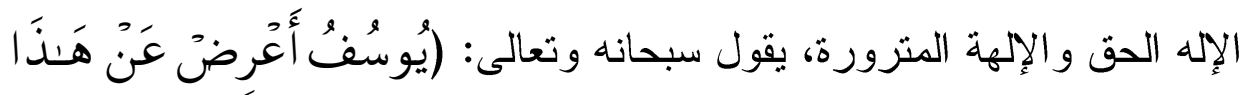

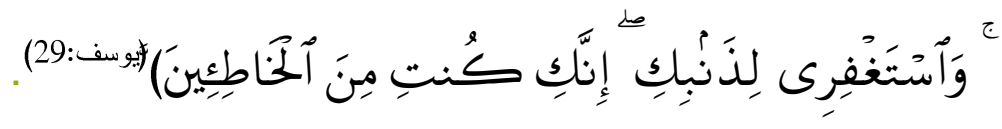


وكان لابد من تتويع أسلوب الحوار والانتقال به من المعقول إلى المحسوس، حتى تزعن العقول. وتزى آيات القرآن الكريم المجيد تفرع العقو ل ل قال تعالى:

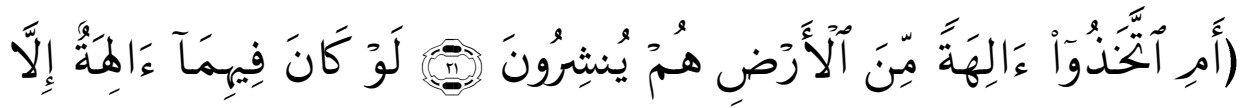

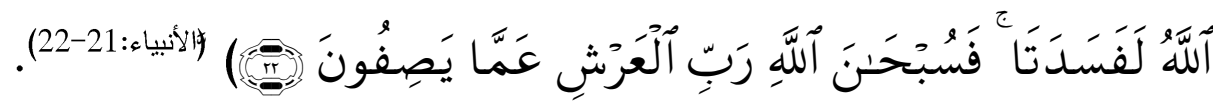

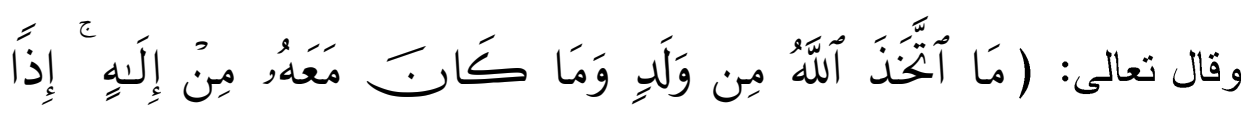

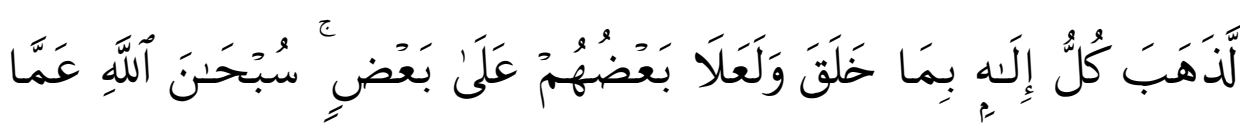
يَصِفُوَِحَ) (المؤمنون:91) فالقران آلكريم يقول لهم يستحيل أن يكون مع الله آلهة، لأن الشركاء دائماً يختلفون و أنتم تشاهدون ذلك بأعينكم. ولكن من الناس من لا يؤمنون إلا بالماديات التي تخضع للتجربة، و القرآن الكريم طرف هذا الإسلوب المادي في المناقشة حول عقبدة التوحيد.

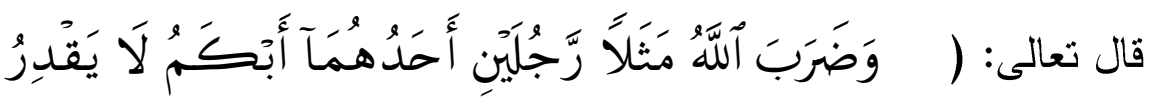

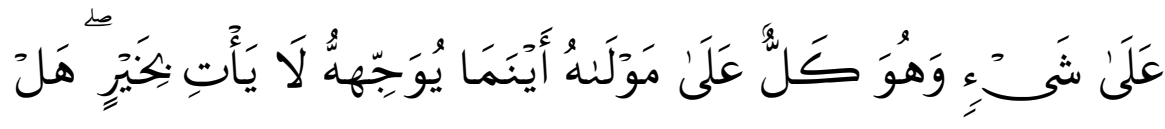

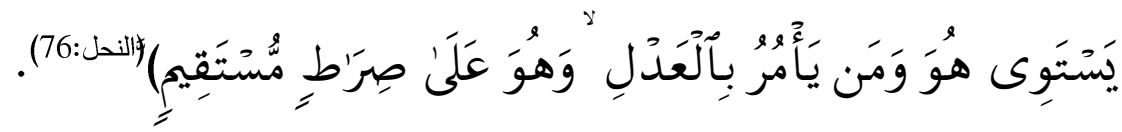
يقول ابن كثير "المراد به الوثن والحق - تعالى - يعني أن الوثن أبكم لا يتكلم و لا ينطق بخير و لا بشر، و لا يقدر على شيء بالكلية فلا مقال و لا فعال،

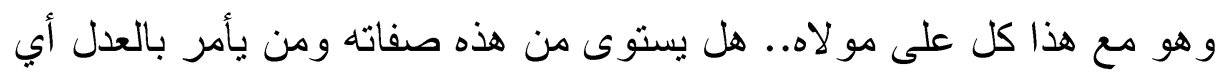
بالقسط فمقاله حق وفعاله مستقيمة" (5). فهذا ولا شك مثل ملموس محسوس، إذ لا ينكر أحد فضل المتكلم على وفى هله الأبكم، ولا فضل المتصرف على العالة، فإذا كان الأمر كذلك بالنسبة لرجلين 
في الو اقع الملدوس لديكم فكيف تفضلون على الله آلهة لا تضر و لا تتفع و لا تبصر و لا تسمع والهه هو السميع البصير؟!!(6).

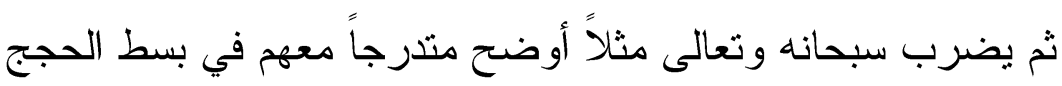
و البر اهين ليفحم المكابرين، ويقر الأمر للر اغبين فيقول تعالى ضَرَبَ أللَّهُ

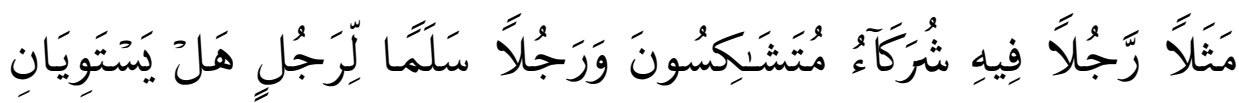

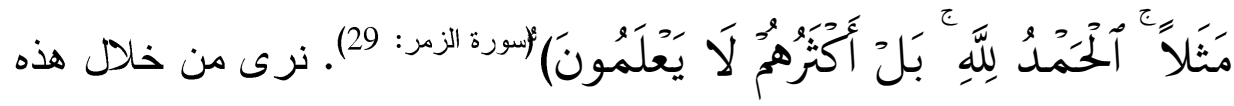
الآية أن العمل مع هؤلاء المشركين وفي هذه المرحلة لابد من فقه يحرك

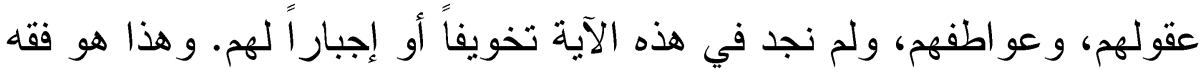

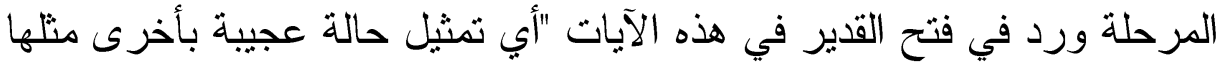
ثم بين المثل فقال: رجلا فيه شركاء متثاكسون" و التشاكس التخالف. قال الفراء

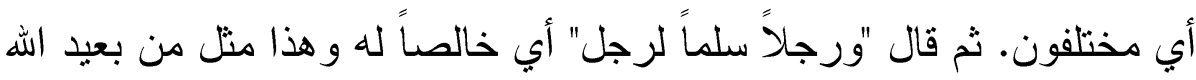

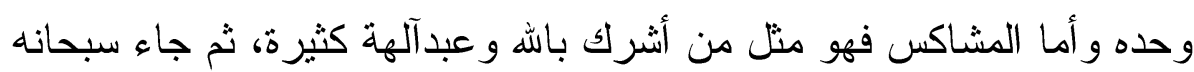

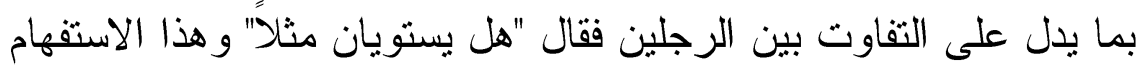

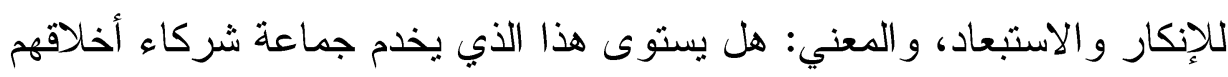

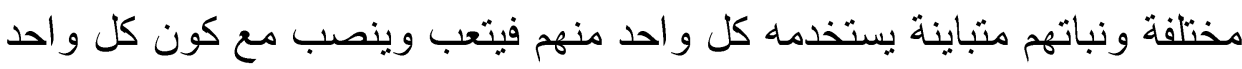

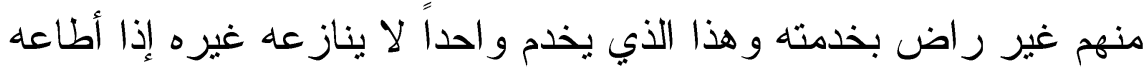
رضي عنه، و إذا عصاه عفا عنه فإن بين هذين من الاختلاف الظاهر الواضح

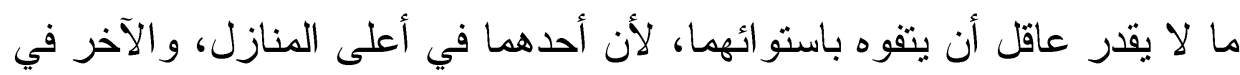

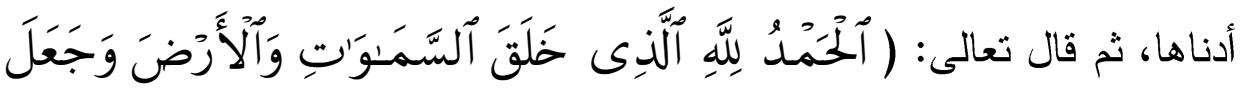

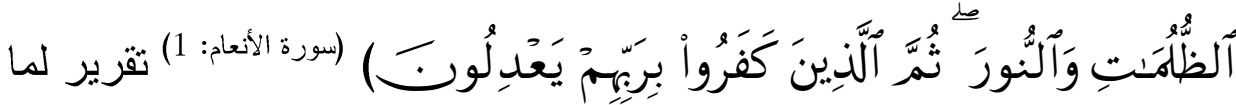
قبلها من نفي الاستو اء، ولإيذان للموحدين بما في توحيدهم لله من النعمة العظيمة المستحقة لتخصيص الحمد به، ثم ضرب سبحانه عن نفي الاستو اء 
الدفهوم عن الاستفهام الإنكاري إلى بيان أن أكثر الناس لا يعلمون فقال: "بل

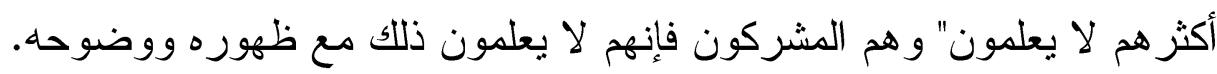

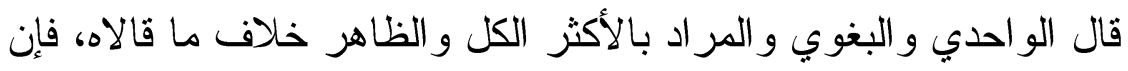

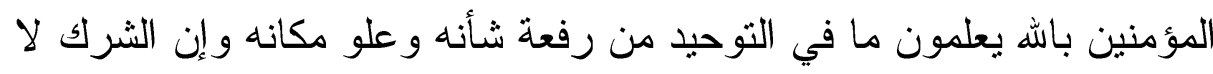

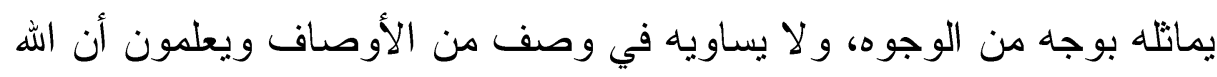

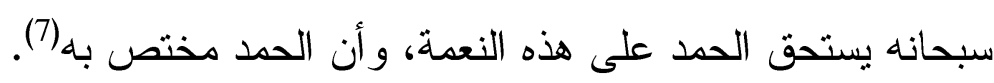

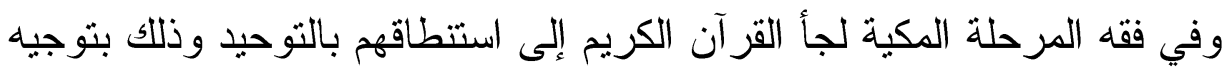

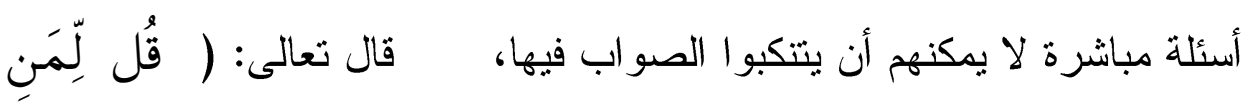

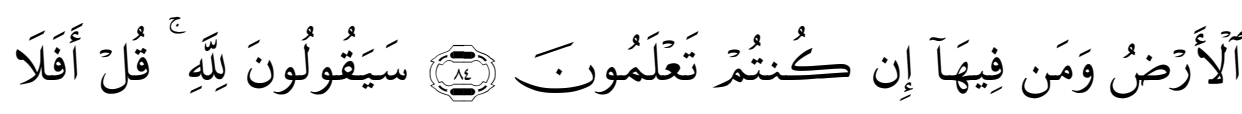

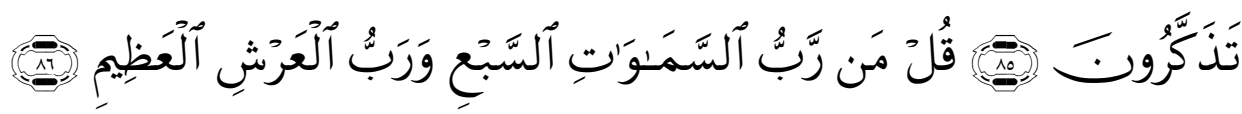

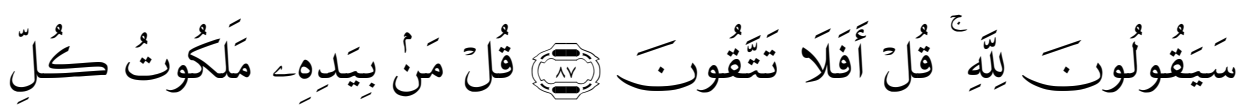

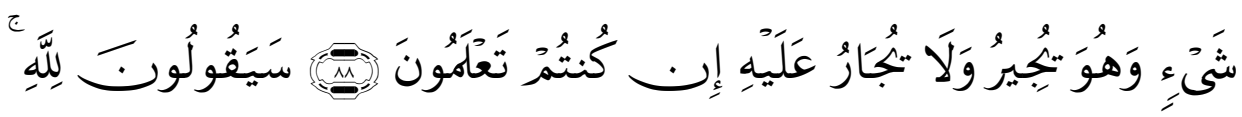

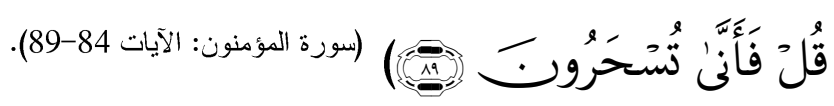

لقد كان مشركو العرب مضطربين في العقبدة لا ينكرون الله، ولا ينكرون أنه ماللك السماو ات و الأرض، مدبر السموات و الأرض، المسيطر على العئ السموات

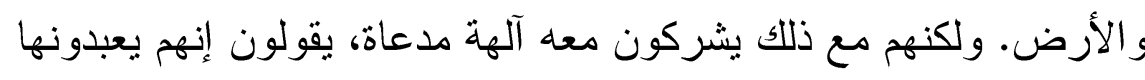
لتقربهم من الله، وينسبون له البنات، سبحانه وتعالى عما يصفون.

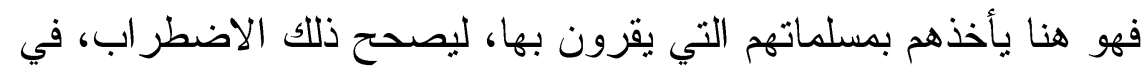
العقيدة، ويردهم إلى التوحيد الخالص الذي تعود إليه مسلماتهم (8).

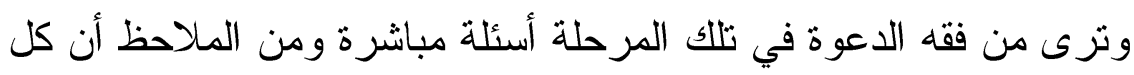
هذه الأسئلة التي وردت في الآيات أسئلة تقريرية، ولقد حاصر بها القرآن الكريم 
كفار قريش في تلك و المرحلة ولم تكن المحاصرة بالتهديد و التخويف وبالسلاح و إنما هي محاصرة ذهنية و هذا من فقه المرحلة. ومن العناصر الهامة التي اعتمد عليها منهج الفترة السرية الإيمان باليوم الآخر.

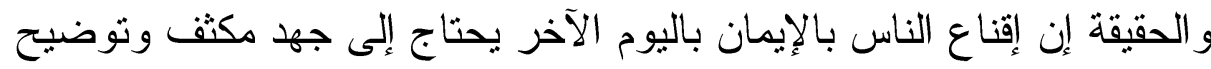

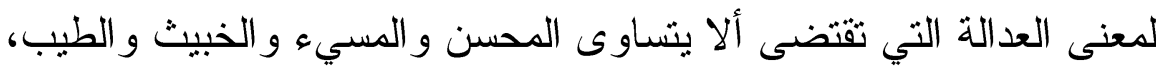

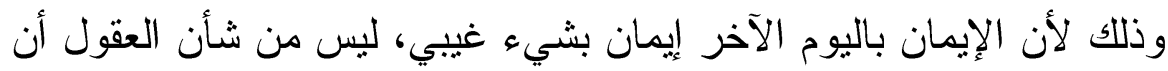

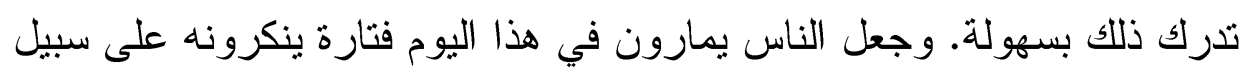

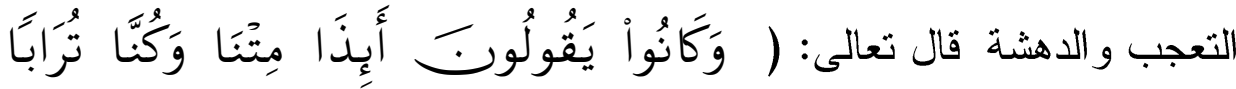

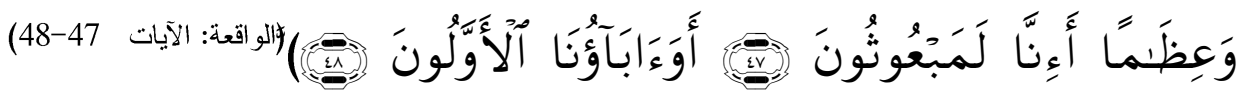

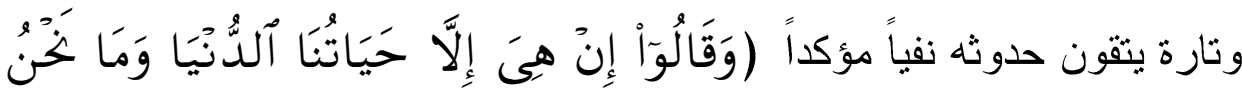
بِمَبْعُوَيِنَ) لالأنعام: 29) وتارة بطلبون الدليل الحسي على صدق الدعو عى قال

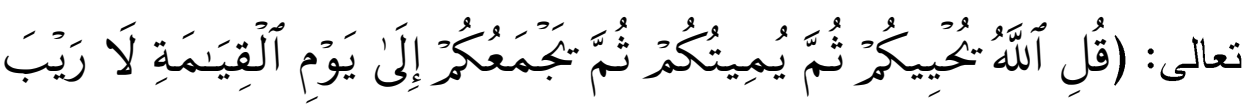

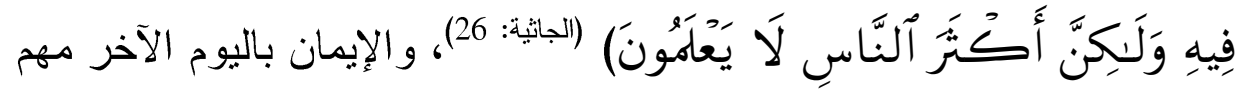
لنطوير الحياة البشرية والسمو بها إلى مرتبة تجعل الناس يسارعون في الخير ات ويتنافسون في الإحسان. ومن أجل تثبيث هذه الحقائق في عقول الناس سلك القرآن آلكريم مسالك

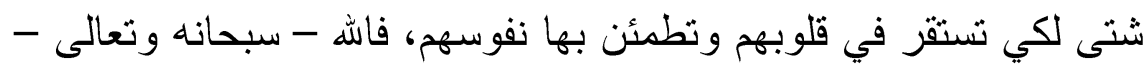
يخوف الناس من أهو ال هذا اليوم ويحذرهم من الإساءة في الدنيا حتى لا يكون المصير سيئًا. 


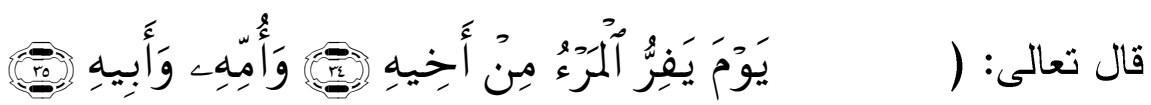

وَصَبحِبَتِهِه وَبَنِيهِ

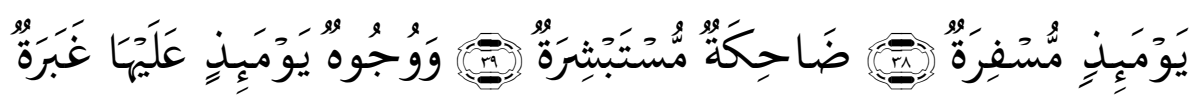

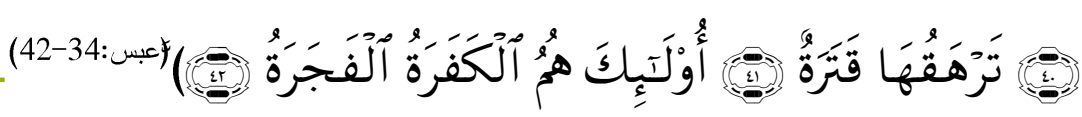

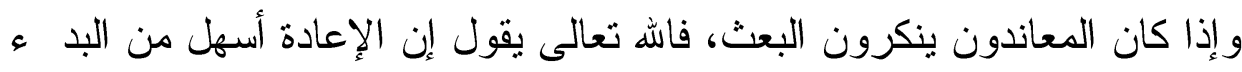

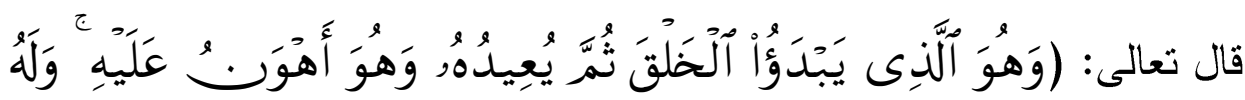

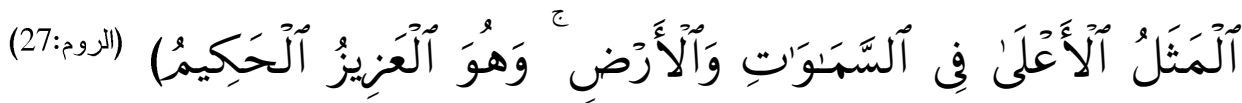

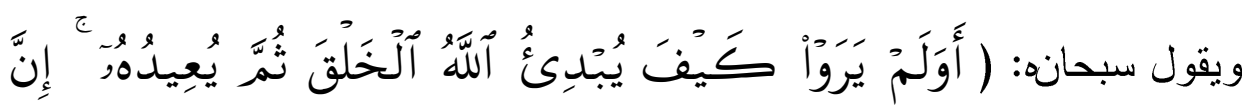

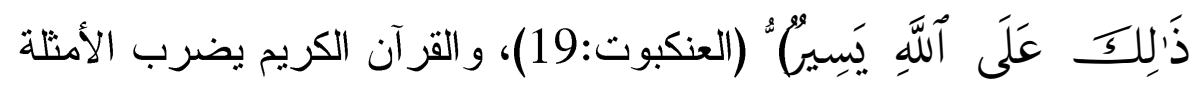

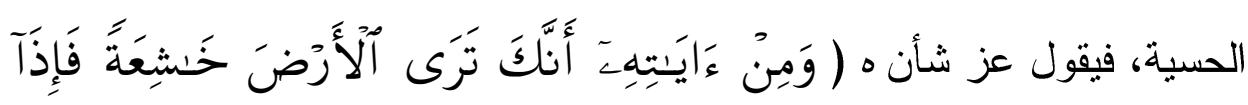

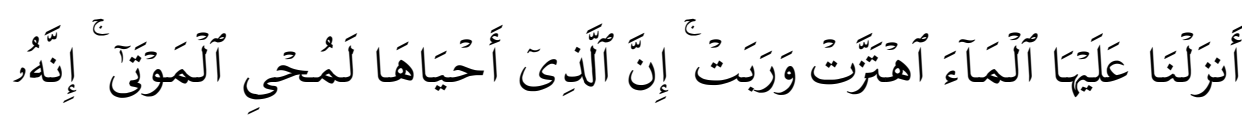

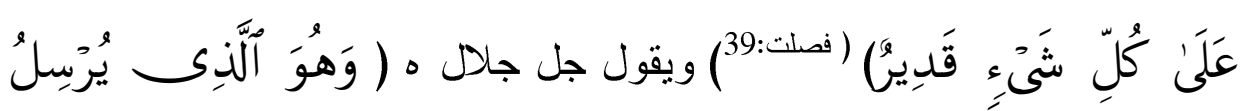

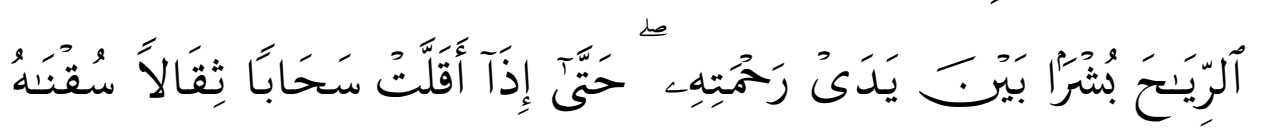

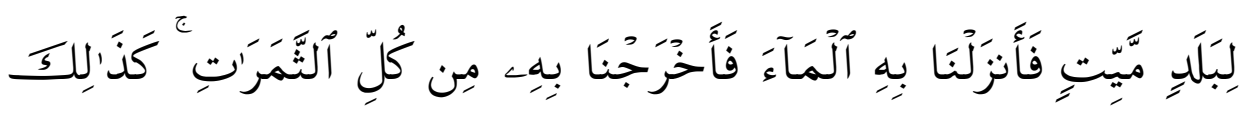

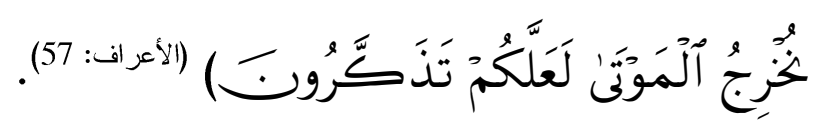


و هكذا يظهر للعقول السليمة أن الإيمان باليوم الآخر ضرورة من ضروريات الحياة السوية القادرة على إفساح المجال للتنافس بين الناس لإبراز أقصى ما يمكنهم إيداعه في الدنيا ليحصلو ا جزاء عملهم في الآخرة. ومشهد آخر من مشاهد اليوم الآخر حيث نرى قوة تأثيره في النفوس البشرية،

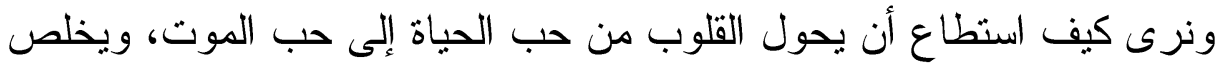
النفوس من التعلق بالمال و الأهل و الولد إلى التعلق بما أعده اله للمؤمنين في

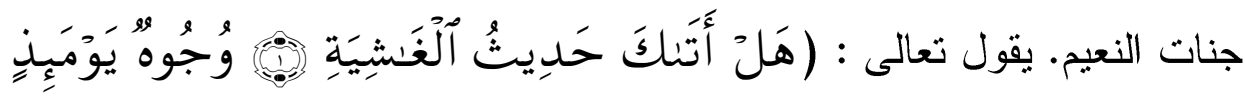

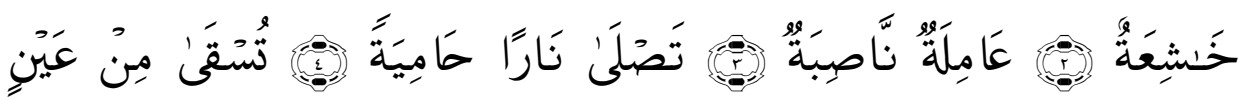

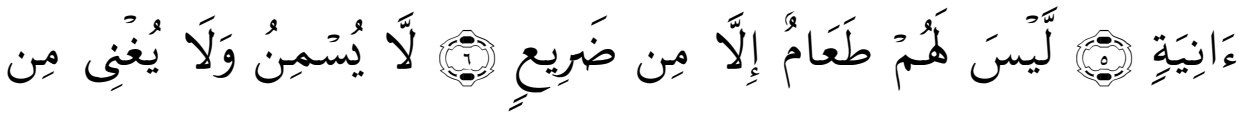

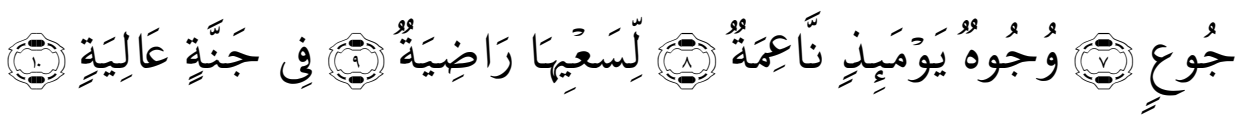

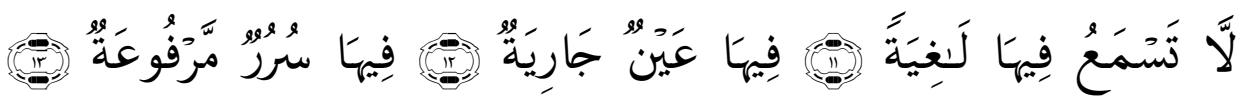

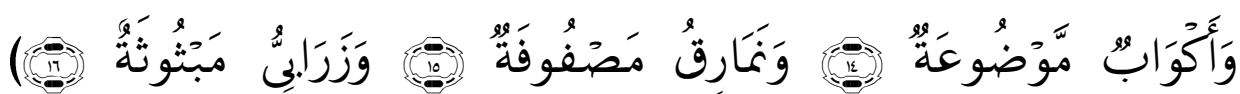
(الغانثية:16) وترى من فقه الدعوة ومن خلال هذه المشاهد التي ذكر ها القر آن الكريم،

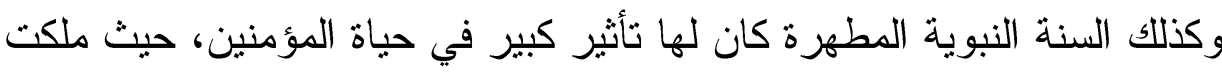

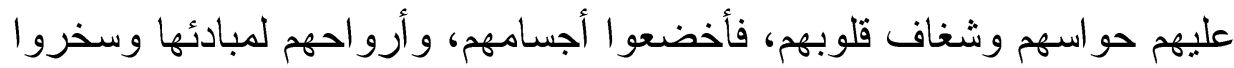

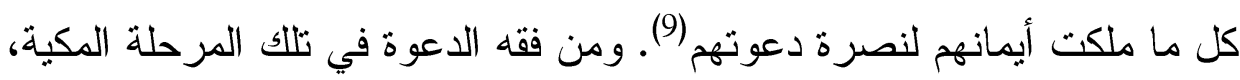

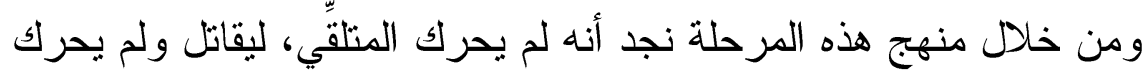

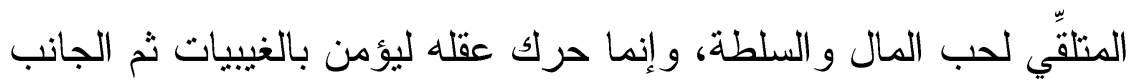
الأخلاقي. 


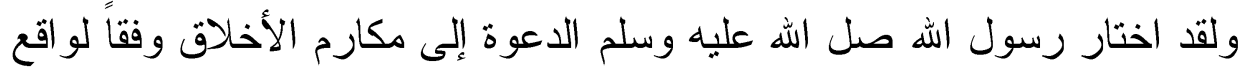
المرحلة. ومن الثواهد على ذلك حيث أمر الرسول صلى الله عليه وسلم

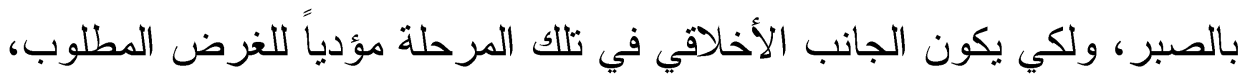

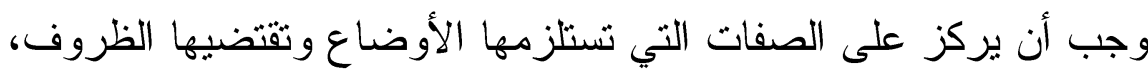

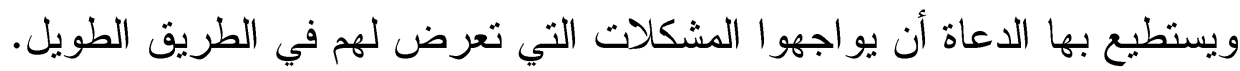

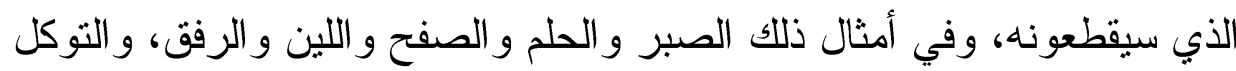

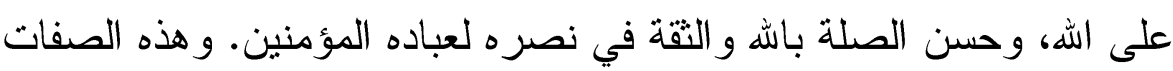

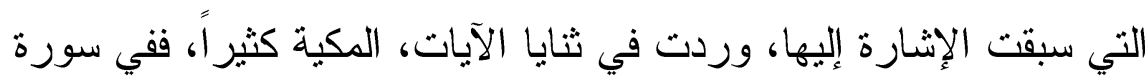

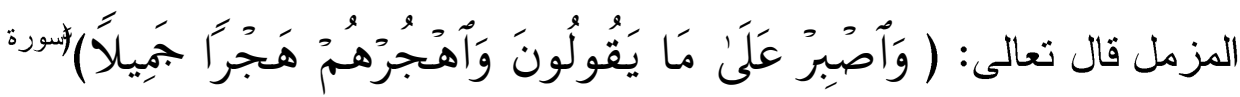
المزمل: 10)يقول ابن كثير يقول تعالى أمراً رسول اله صل اله عليه وسلم بالصبر

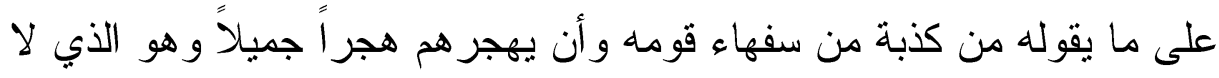

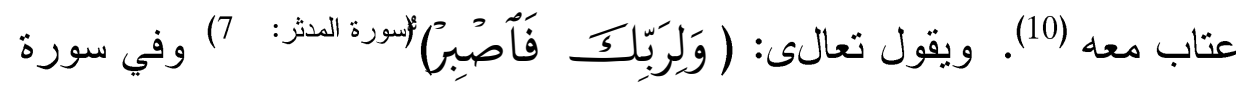

الضحى وهي كذلك من سور تلك الفترة بأمر الله نبيه عليه الصلاة والسلام

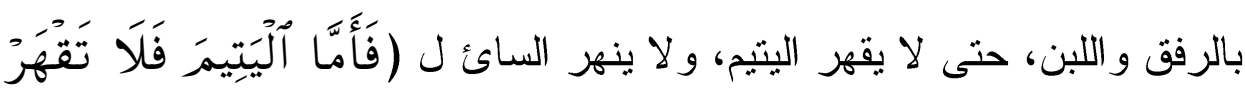

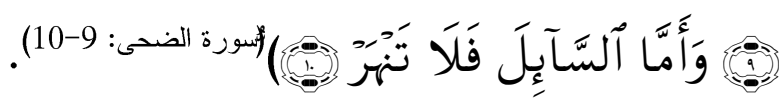

كما حذَّر تعالى من الوقوع في النميمة، وهي خلق سيئ يقطع أرحام المجتمع،

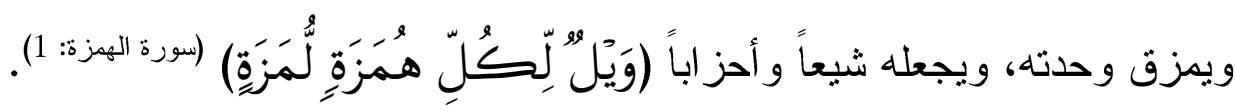
وبعد هذا العرض يأتي دور التساؤل هل أدى هذا المنهج الغرض

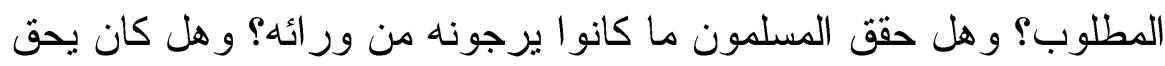

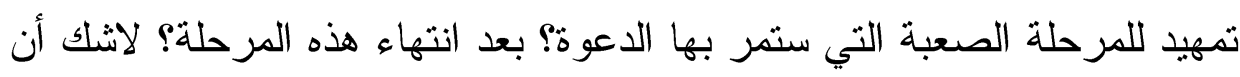

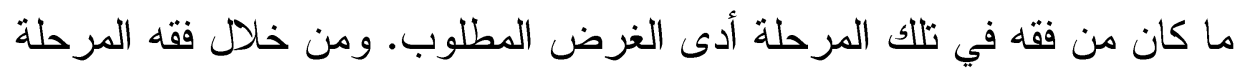
المكية تلك كان فيه خلاص المدعوين من مواجهة الأعداء، وكان أن وجدت 
الدعوة طريقها إلى القلوب بالتثرج في الدكان الذي أر اده الله تعالى فانتقلت من

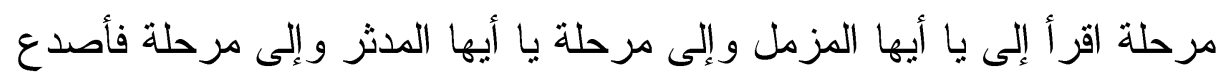

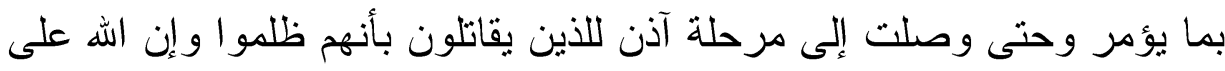
نصر هم لقدير. 


\section{المبحث الثالث}

\section{دعوة الأفر اد في المرحلة المكية}

في هذا المبحث ورد أن علياً آمن برسول الله صلى الله عليه وسلم، وصدق بما جاءه من الله تعالى، وهو يومئذٍ ابن عشرة سنين، وكان مما أنعم الله به على عليَّ رضي الله عنه أنه كان في حجر رسول الله صلى الله عليه وسلم، كأل قبل الإسلام لأن أبا طالب كان كثير العيال، فأخذ رسول الهه صلى الهه عليه وسلم علياً وضمه إليه ولم يزل معه حتى بعث الله رسول صلى الله عليه وسلم رسولاً و اتبعه على، وذكر بعض أهل العلم أن رسول الله صلى الهه عليه وسلم كان إذا حضرت الصلاة خرج إلى شعاب مكة، وخرج معه علي مستخفياً من أبيه، حيث

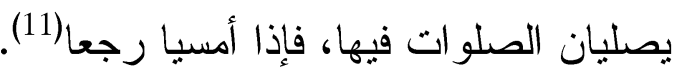
وورد أن سبب إسلامه أنه دخل على النبي صلى الله عليه وسلم، ومعه

خديجة رضي الله عنها وهما يصليان، فقال ما هذا؟ فقال رسول الله صلى الله عليه وسلم دين الله الذي اصطفاه لنفسه وبعث به رسوله، فأدعوك إلى الله، و إلى عبادته و الكفر باللات و العزى فقال له علي: هذا أمر لم أسمع به قبل اليوم، ولست بقاضي أمراً حتى أحدث أبا طالب. وكره الرسول صلى الله عليه وسلم أن يفشى سره قبل أن يستعلن أمره فقال له: يا علي إن لم تسلم فأكتم هذا. فمكث على هداه إلى الإسلام فأصبح غادياً إلى رسول الله صلى الله عليه وسلم فأسلم على بديه (12).

وبهذا نرى أن الرسول صلى الله عليه وسلم و علياً بصليان في الخفاء

لأن الدعوة في لحظتها لم تكن للمو اجهة و العلن، كما تشير الآيات المكية التي تتنزل في تلك اللحظات، وأن الرسول صلى الله عليه وسلم قال له إن لم تسلم فأكتم هذا، و هذا هو أسلوب التدرج و الفقه الذي يأخذ من الضعف إلى القوة على حسب ما بناسب الموقف. 
ثم كان من الذين سمعو ا بالرسول صلى الله عليه وسلم أبا ذر الغفاري رضي الله عنه، حيث وصل إلى مكة المكرمة، وكان إسلامه وفقا للتنرج في

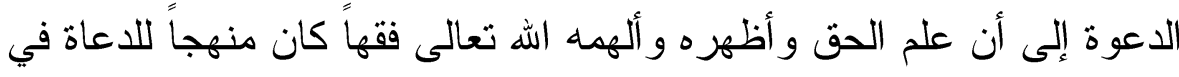
المستقبل، ومخرجاً لمشكلة الدعوة في وقتها الحاضر .

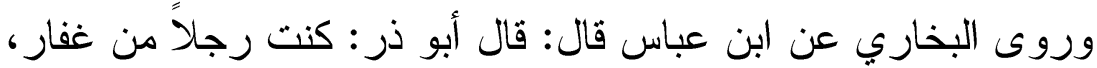

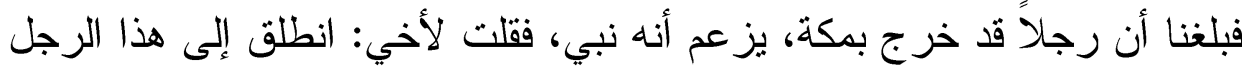
وكلمه، و ائتتي بخبره، فانطلق فلقيه، ثم رجع، فقلت: ما عندك؟ فقال: و الله لقد

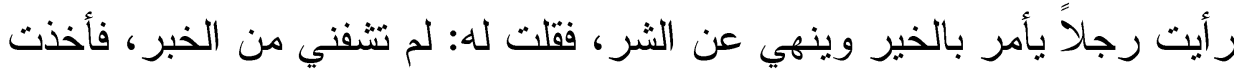

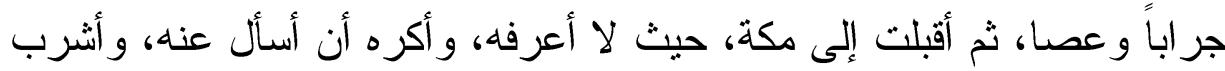

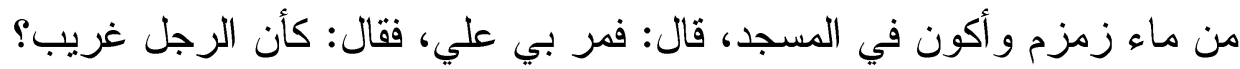

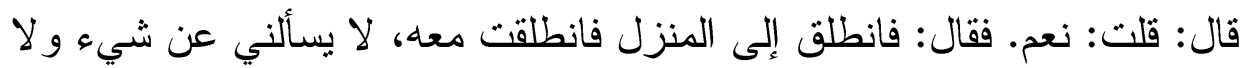

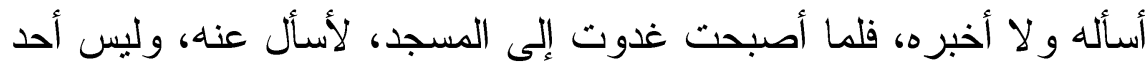

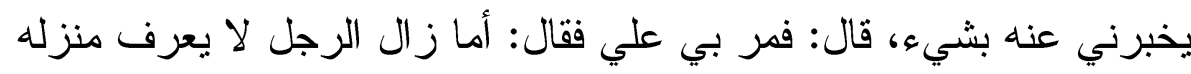

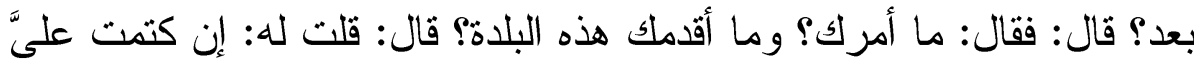

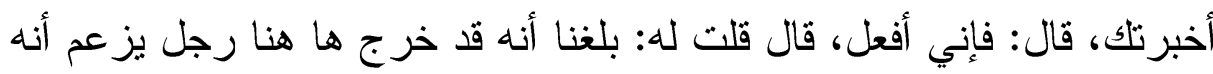
نبي الله فأرسلت أخي يكلمه، فرجع فلم يشفني من الخبر، فأردت أن ألقها، فقال له أما إنك قد رشدت، هذا وجهي إليه، أدخل حيث أدخل، فإن رأيت أحداً أخافه

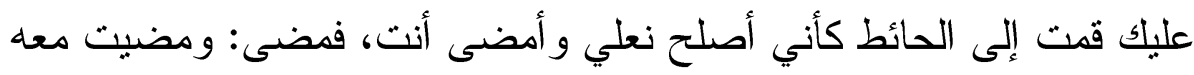

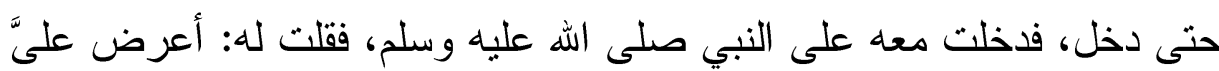

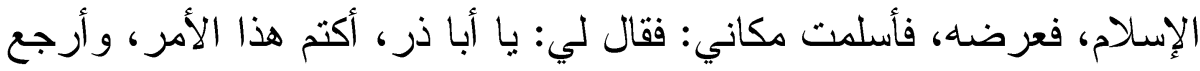

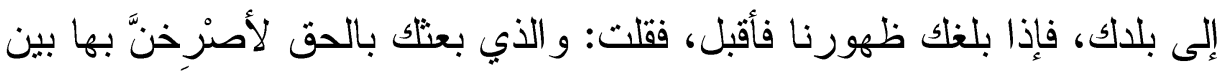

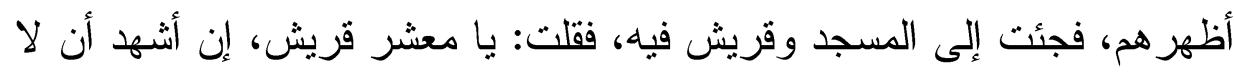

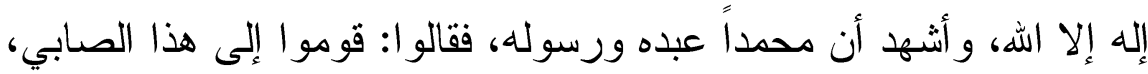
فقامو ا فضربت لأموت، فأدركني العباس، فأكبَّ علىَّ، ثم أقبل عليهم فقال: ولى وليلكم 


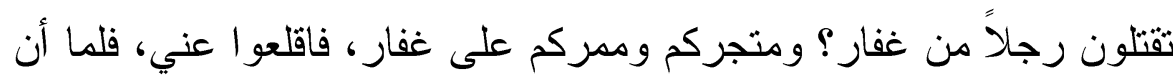

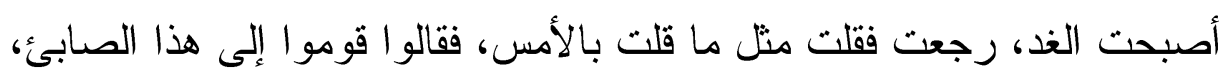

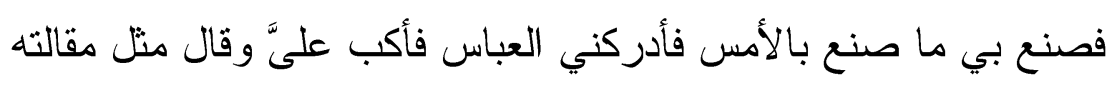

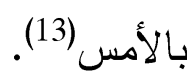

وبعد هذا العرض في إسلام أبي ذر نلاحظ فقه الدعوة من خلال كلماته

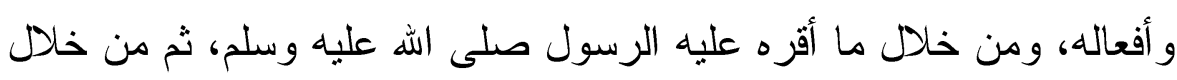

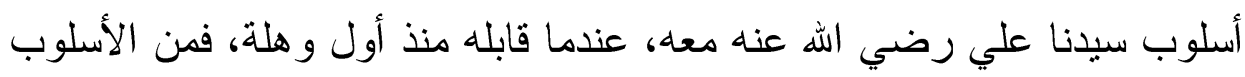

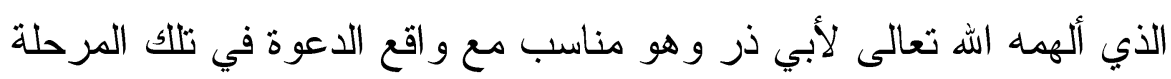

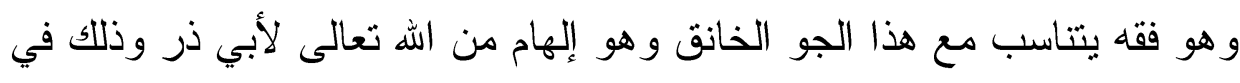

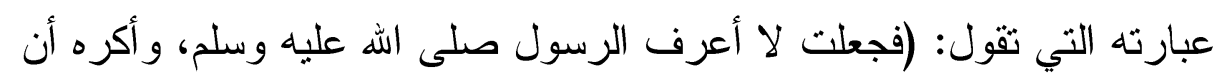

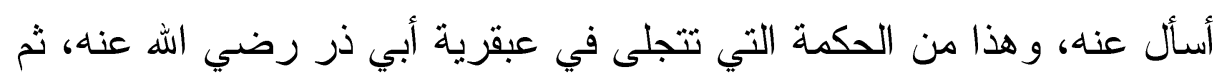

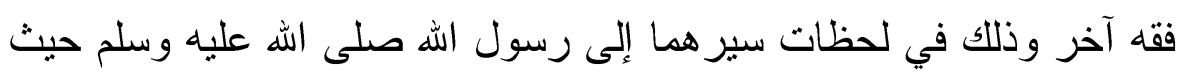

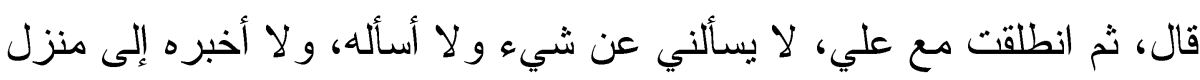

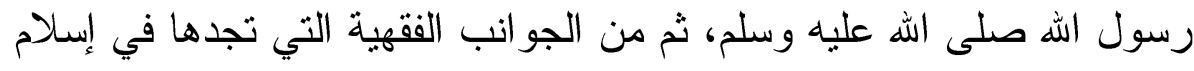

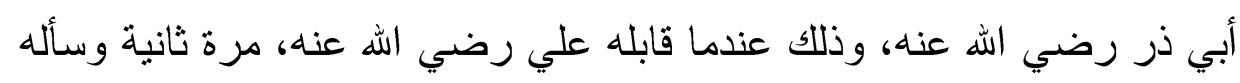

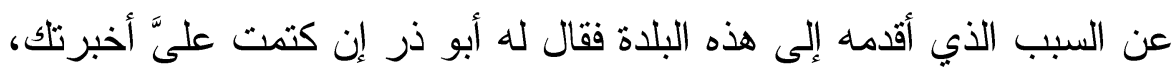

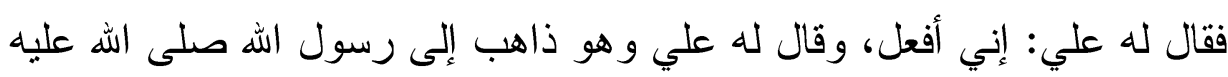

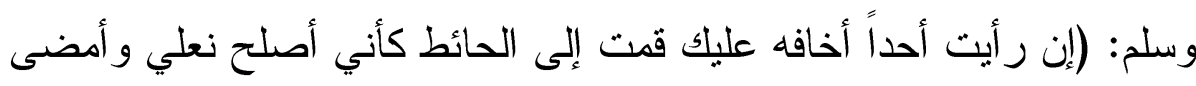

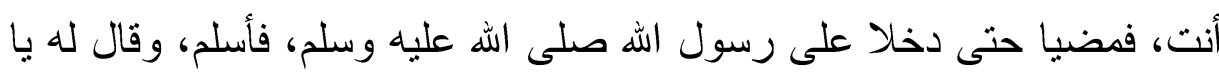

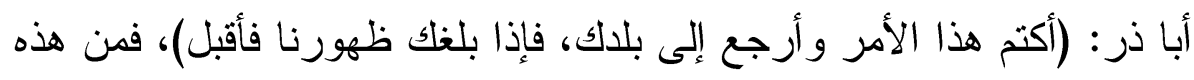

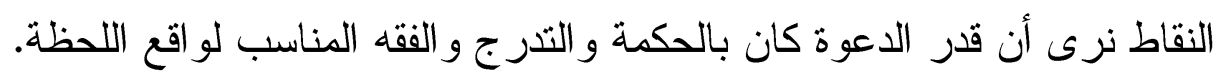

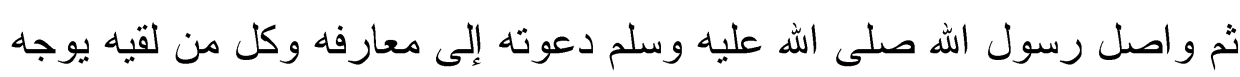

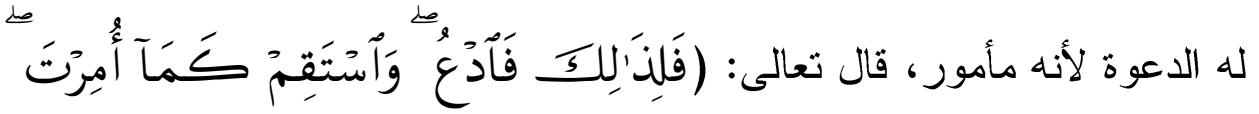




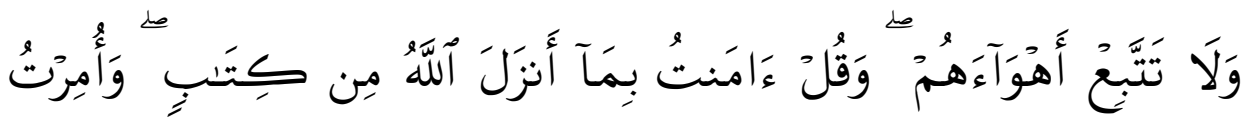

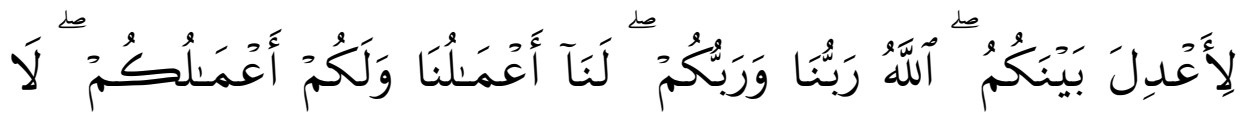

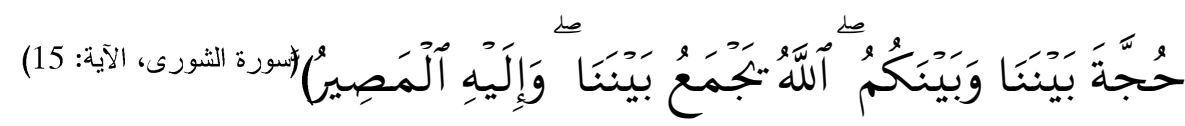
واصل رسول اله صلى الله عليه وسلم دعوته على حسب فقه المرحلة

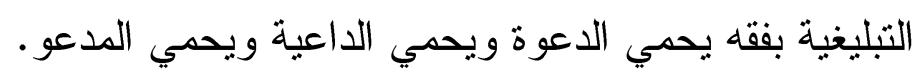

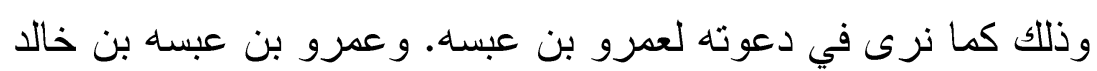

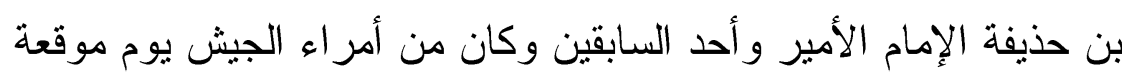

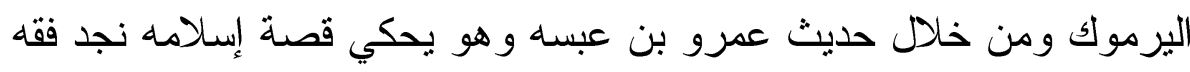
الدعوة في هذه المرحلة التبليغية حيث قال: (أتيت رسول الله صلى الله عليه

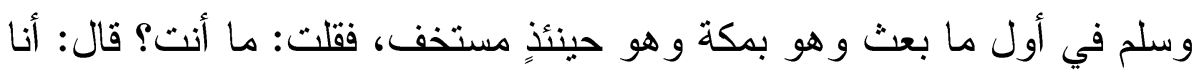

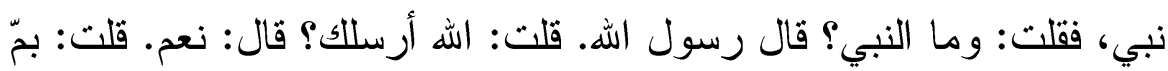

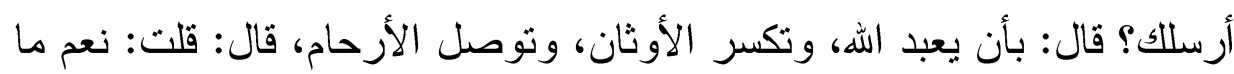

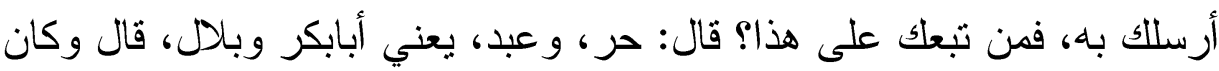

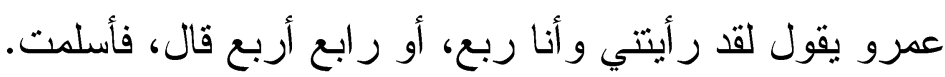

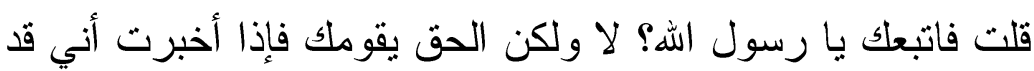

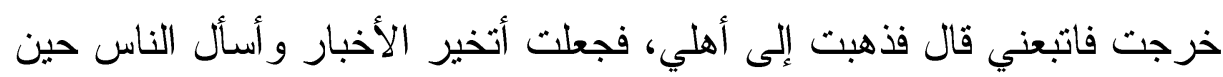

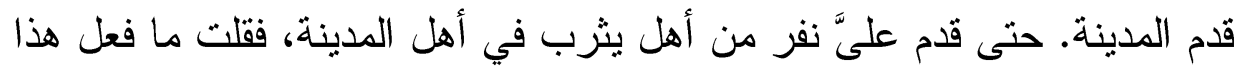

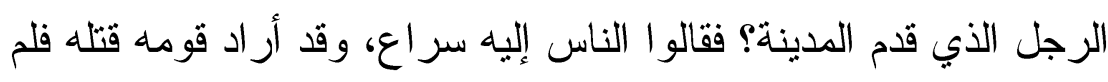

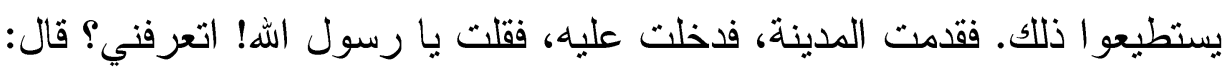

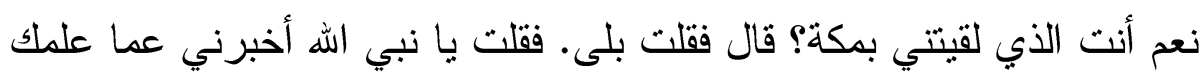

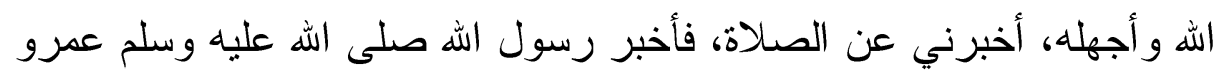

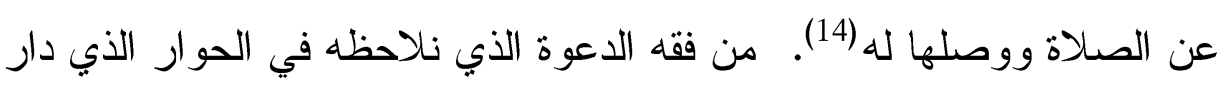
بين عمرو وبين رسول اله صلى الله عليه وسلم، نرى أن الرسول صلى اله له لهائ 
علبه وسلم كان مستخفياً وذلك لأن الدعوة لم يأت الأمر بالظهور بها، ثم أن

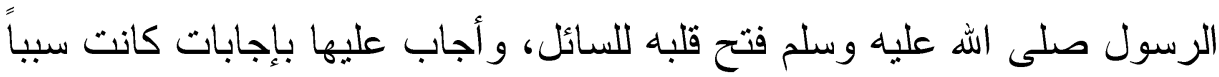

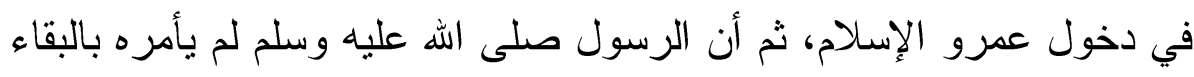

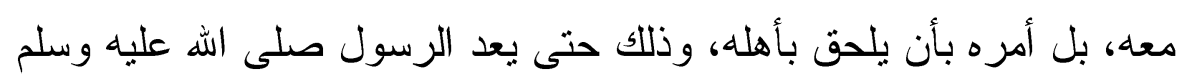

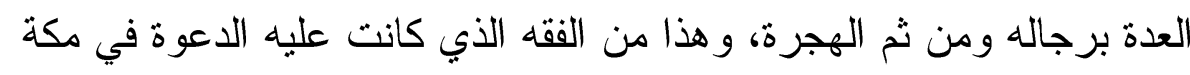
المكرمة. ولقد و اصل رسول الله صلى الله عليه وسلم دعوته إلى معارفه الذين

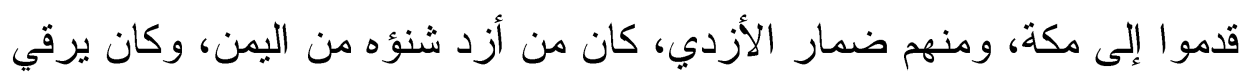

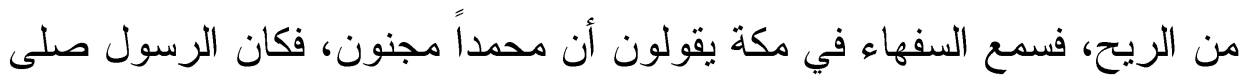

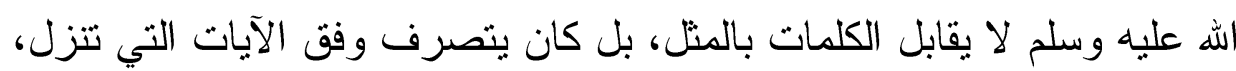

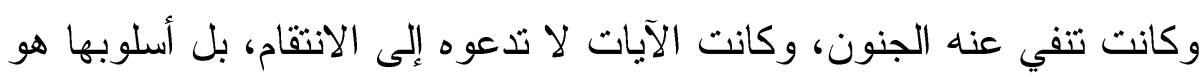

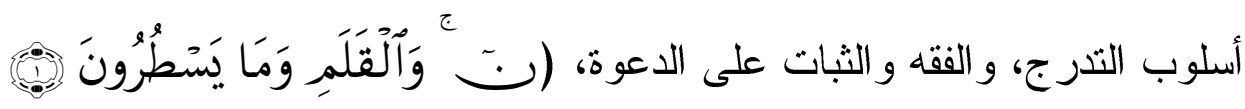

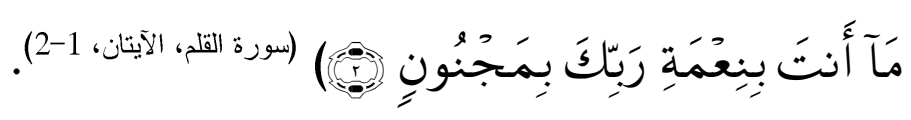

ولذلك عندما قابله ضما د الأزدي، قال للرسول صلى اله عليه وسلم با

محمد، إني أرقى من هذا الريح، فهل للك؟ فلم يقابله الرسول صلى الله عليه

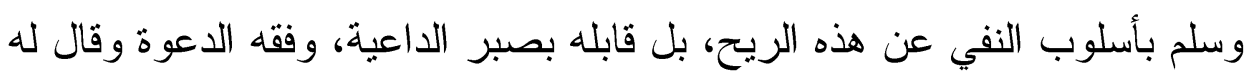

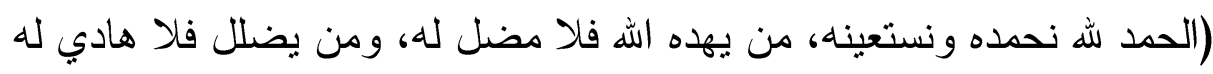

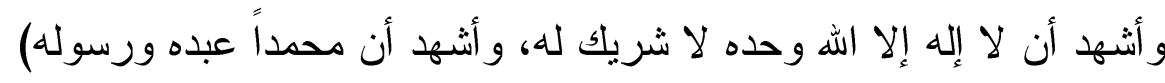

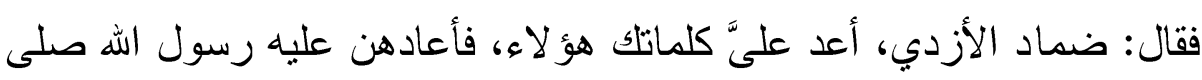

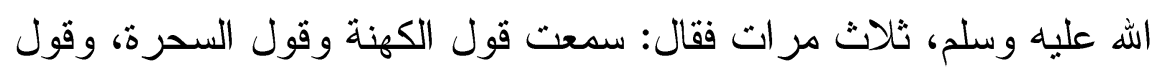

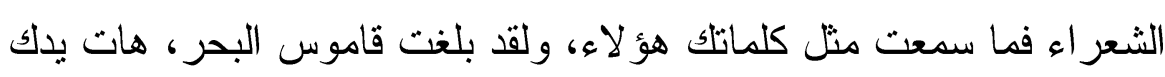

$$
\text { أبايعك على الإسلام فبايعه(15). }
$$

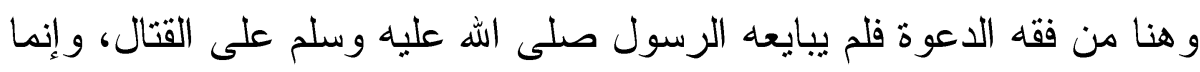

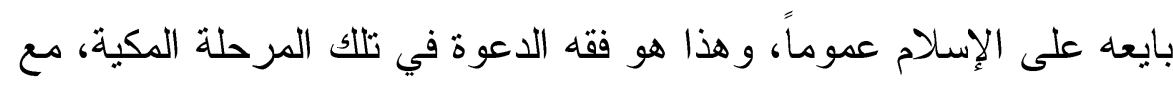


الأفر اد و الجماعات وكذلك كان أسلوب القر آن الكريم، يرد على الجميع دون

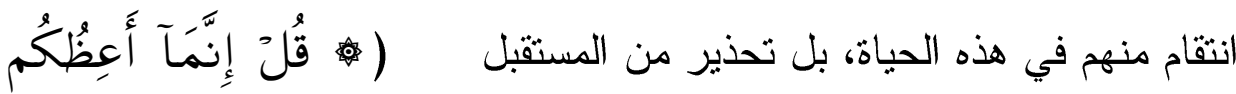

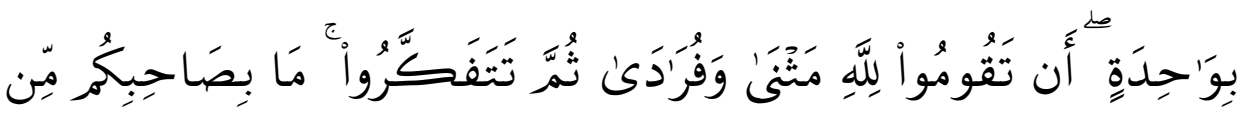

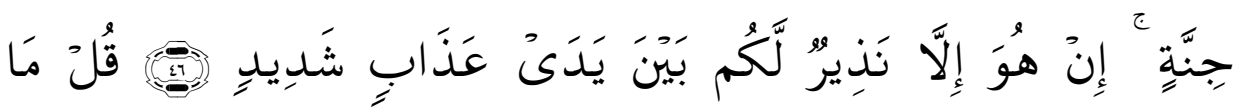

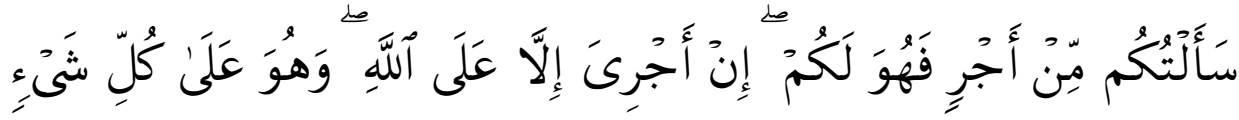

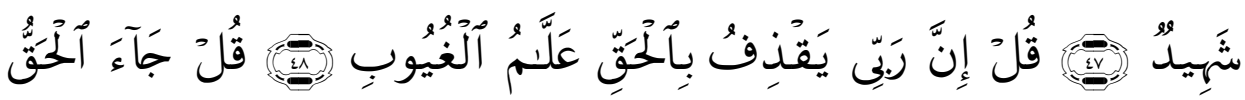

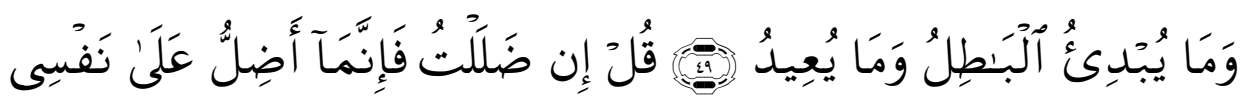

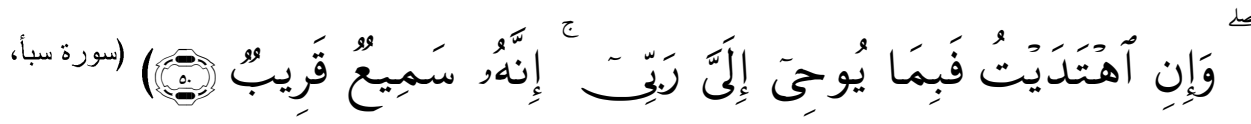

في صدر الآيات جاء الأمر بالقيام والتفكر في أمر الجنون، وهذه الآيات

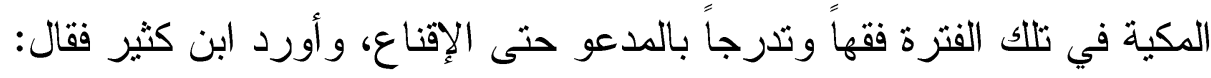

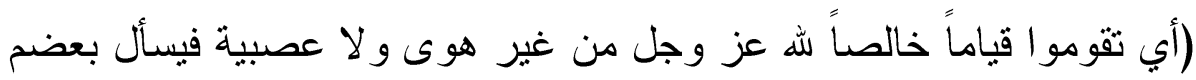

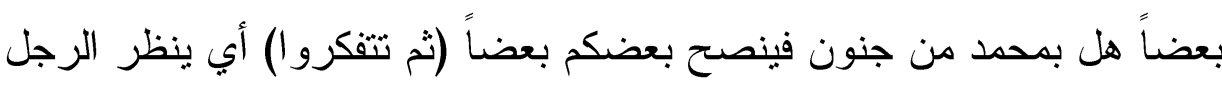

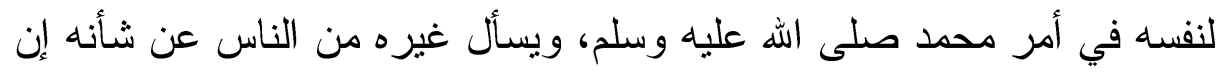
أشكل عليه ويتفكر في ذلك (16). ومن الملاحظ في الآيات المتقدمة أنها لا تدعو إلى قتال و لا إلى مو اجهة بأي صورة من صور القتال، وإنما كان الأمر تفكير في الأمر أي (تتفكروا)

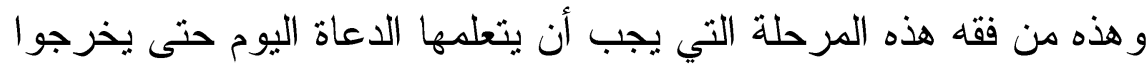

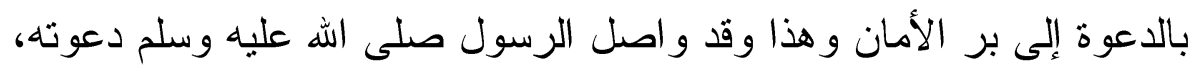

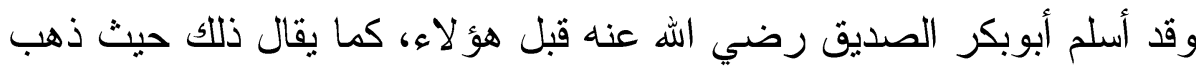


جماعة إلى أنه أول من أسلم. فقال الثعبي: (سألت ابن عباس من أول من أسلح؟

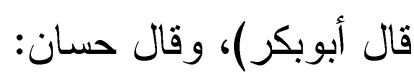

و الثاني التالي المحمود مشهده ** و وأول الناس قدما صدق الرسلا

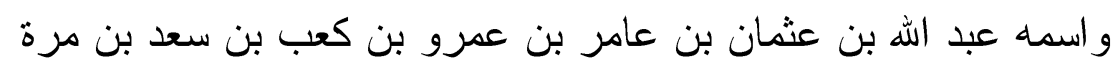

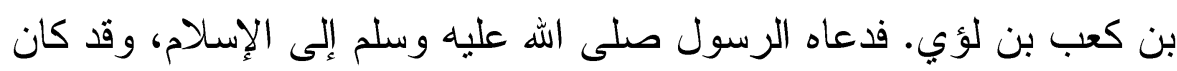

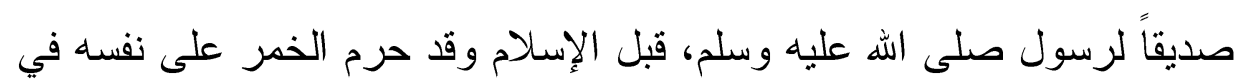

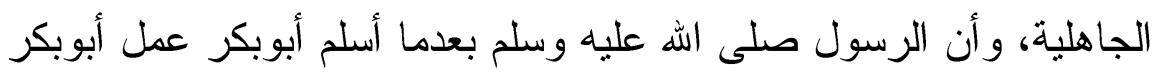

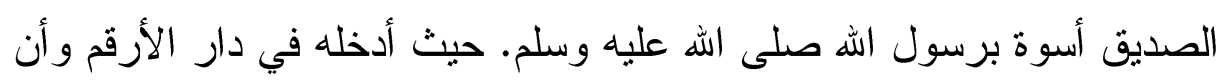

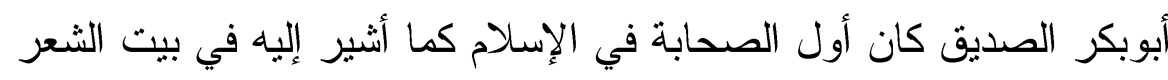

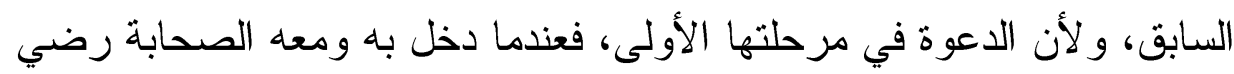

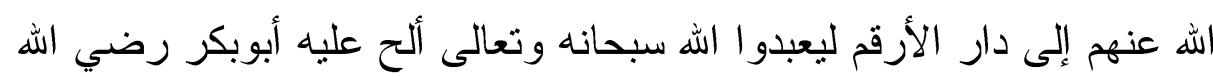
عنه إلى الظهور، فقال له الرسول صلى الله عليه وسلم يا أبا بكر إنا قليل.

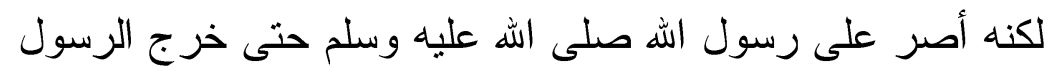

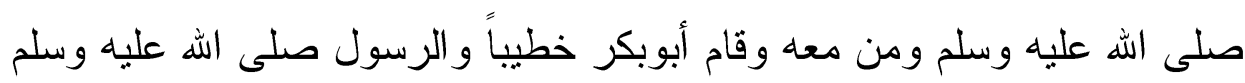
جالس ودعا إلى رسول الله صلى الله عليه وسلم فتار المشركون على أبوبكر إبكر رضي الله عنه، وضربوه ضرباً شديداً (17).

ونجد في عبارة الرسول صلى الله عليه وسلم (يا أبابكر إن قليل) فهذه العبارة

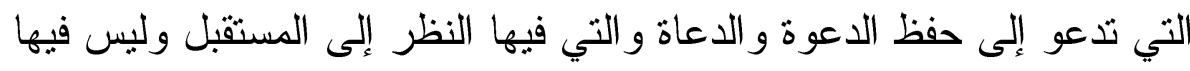

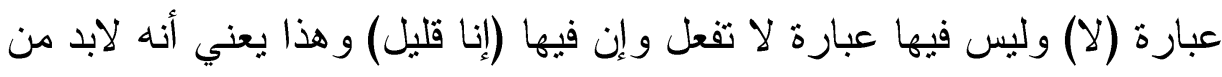

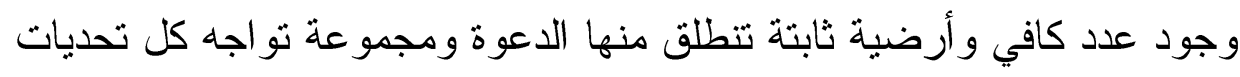

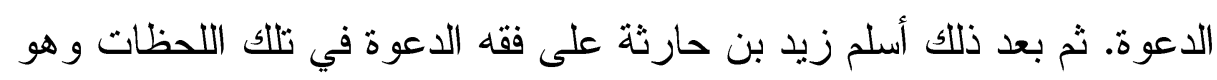

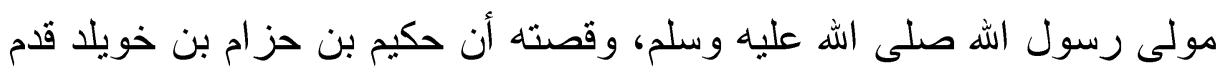

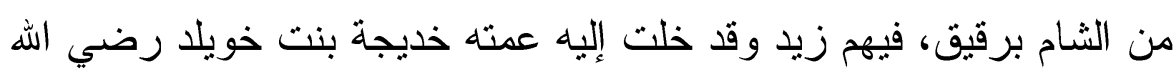

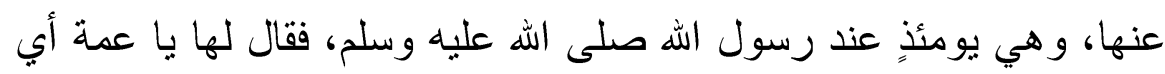


هؤ لاء الغلمان شئت فهو للك، فاختارت زيداً، فر آه رسول الله صلى اله عليه وسلم عندها فاستو هبه منها فو هبته له، فاعنقه رسول الله صلى اله عليه وسلم،

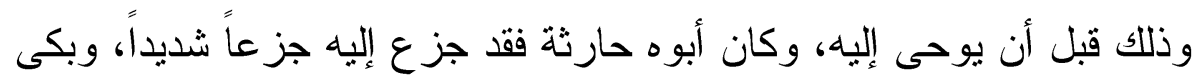

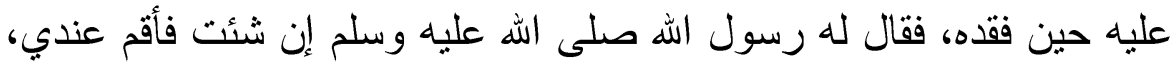

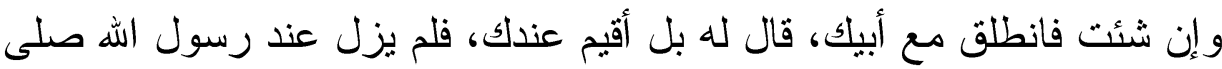

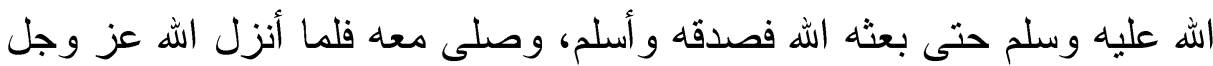

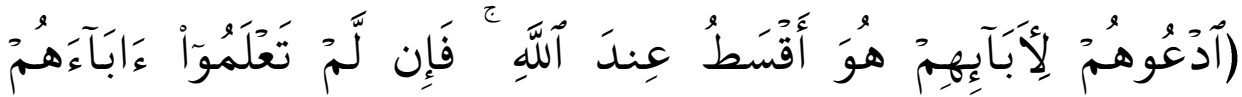

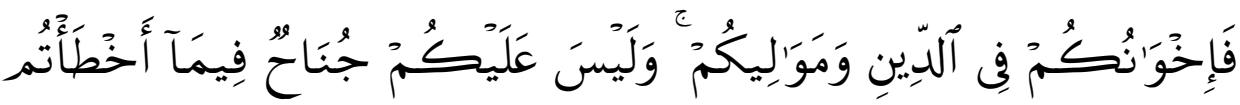

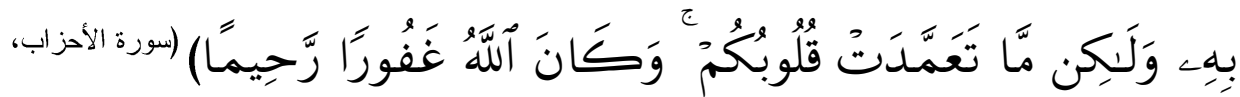
الآية: 5) قال أنا زيد بن حارثة (18). وبناءٌ على ما تقدم نجد أن الدعوة إلى الله تعالى قامت على بصيرة وكان لابد لها من فقه قدَّر الله تعالى لها أن تكون عليه، وقد قام رسول الله صلى الله

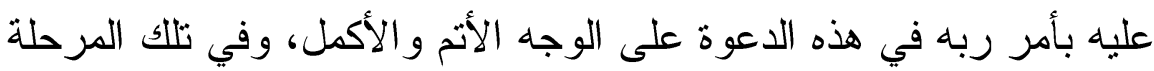
المكية حتى كانت على ما كانت عليه. وذلك كما نرى في المبحث الخامس وهو الته أسلوب الحوار في المرحلة المكية. 


\section{المبحث الر ابع}

\section{أسلوب الحوار في المرحلة المكية}

(الإسلام دين يهتم بالتخطيط و الدراسة، ويدعو إليهما دعوة جادة

وو اعية، ولم يقتصر في دعوته هذه على النظرية الافتراضية لأنه يعلم أن الناس

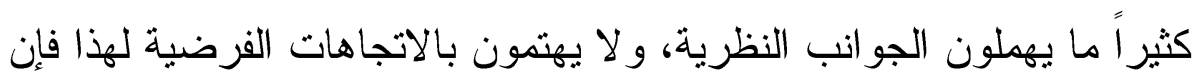

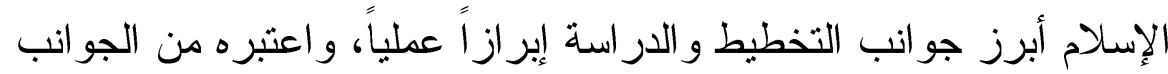

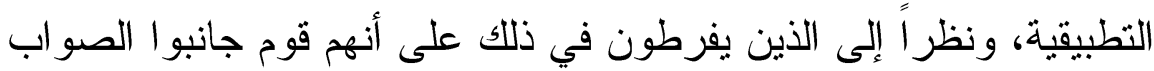
و انحرفوا عن الجادة وهم لذلك لا يستحقون عون الله وتأييده.

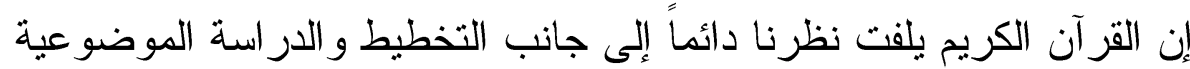

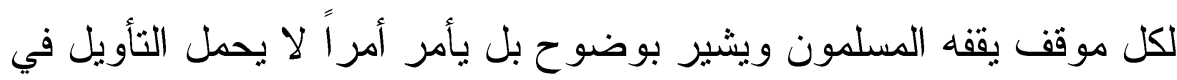

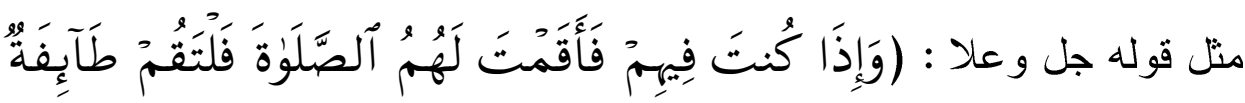

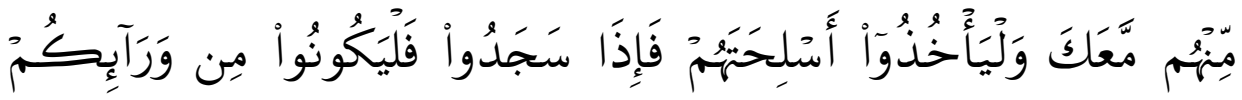

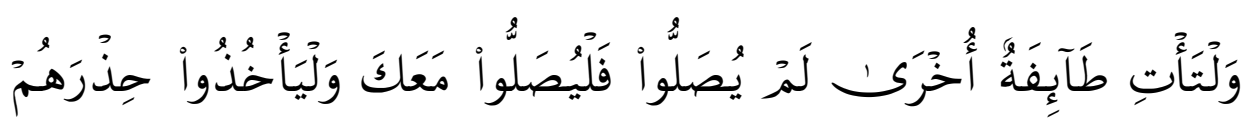

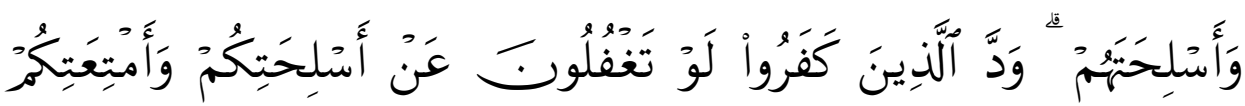

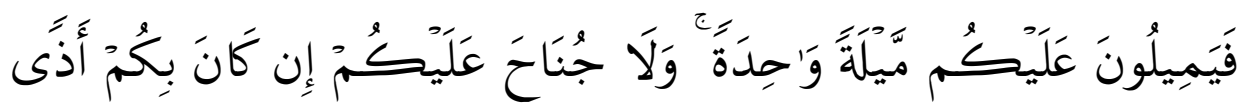

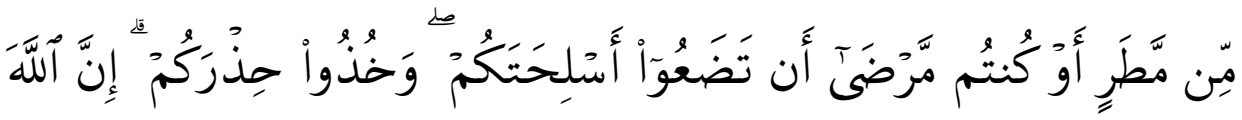

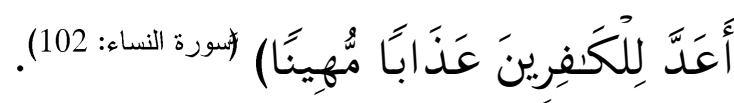

هذه الآية الكريمة من القر آن المجيد ترسم لنا خطة معركة عسكرية في

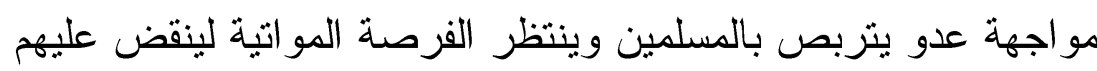
انقضاض الوحش الجائع على فريسة غافلة، وهو بذللك ينبه على منهج المسلمين 
في كل تصرفاتهم، فلبس ذلك في الحرب فقط، بل هو عام في السلم و الحرب،

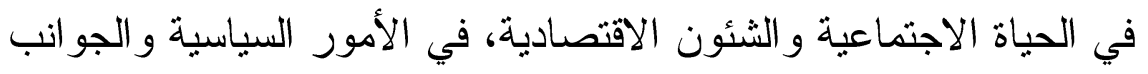

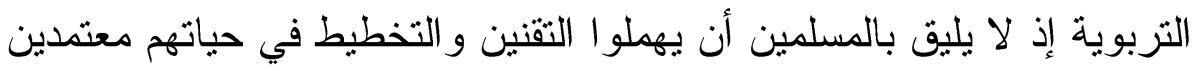
على تأييد الله لهم ومعونته إياهم.

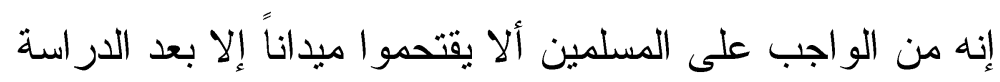

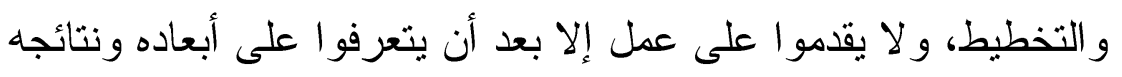

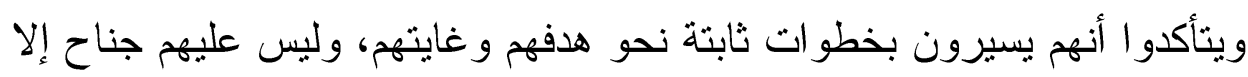

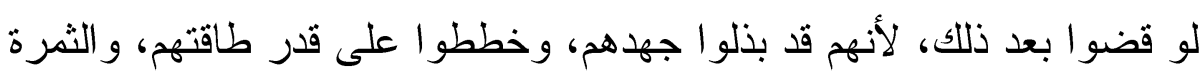

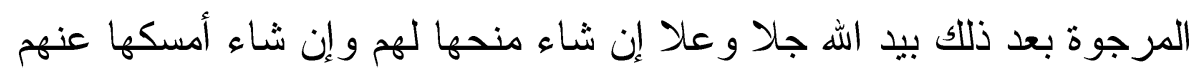

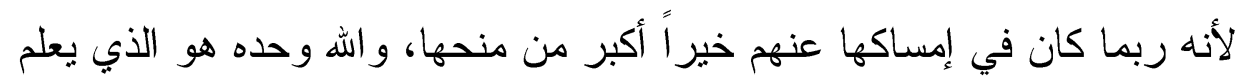
ذللك ويقدره لعباده..

إن النخطيط سمة من سمات العمل الإسلامي الناجح، و الفوضي ضرب

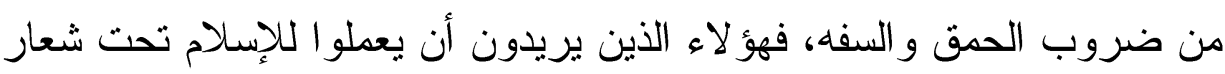

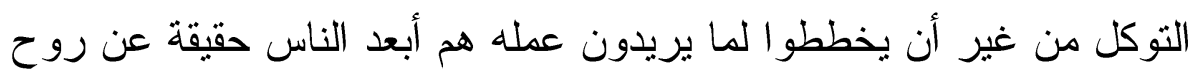
الإسلام وتعاليمه، و الذين يحسبون أن العمل للإسلام إنما هو دروشه وبه وبله

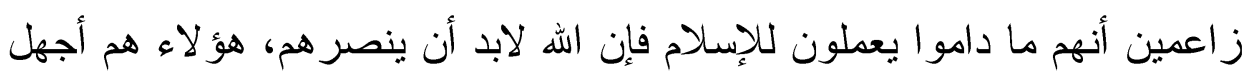

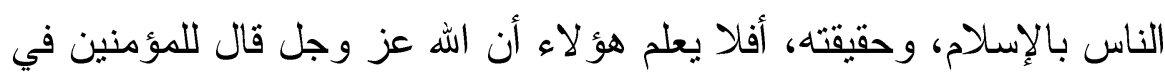

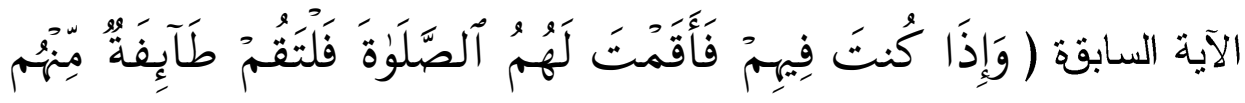

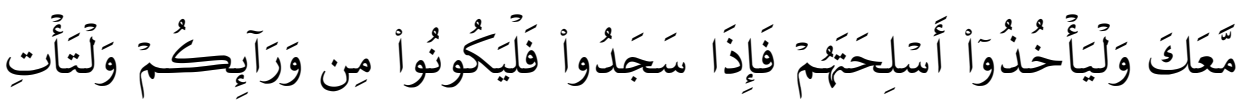

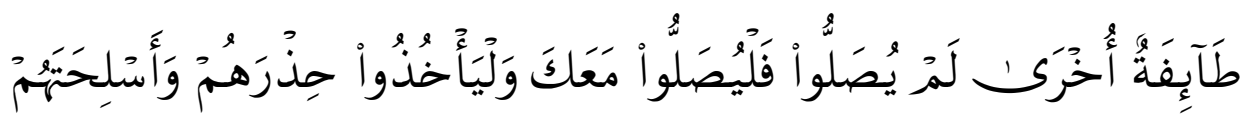

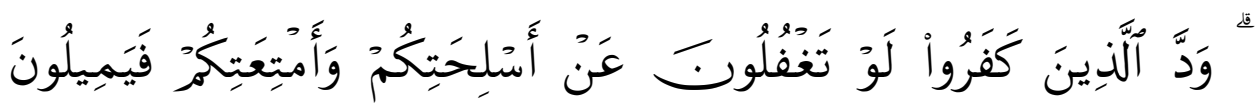

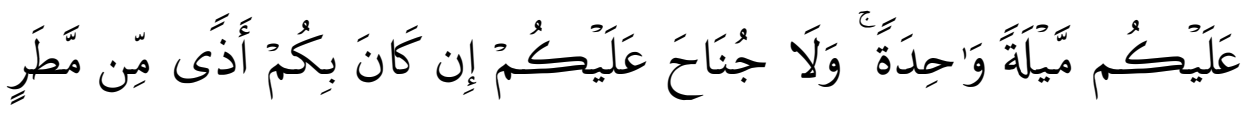




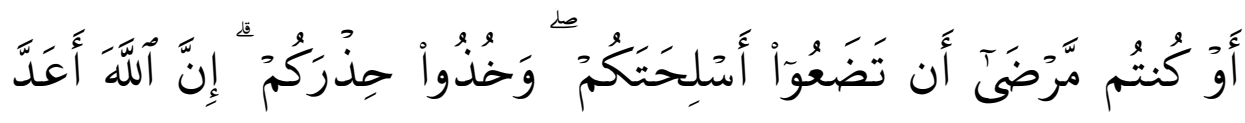

$$
\text { لِلْكَفِرِينَ عَذَابًَا مُهُهِينًا). }
$$

وهل لأخذ الحذر معنى سوى الاحتياط حتى لا يفاجأ المسلمون بما

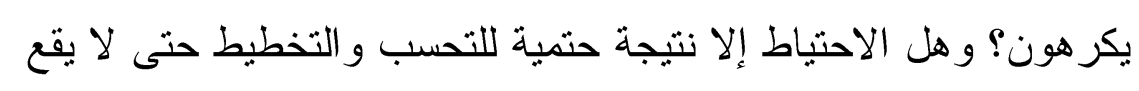

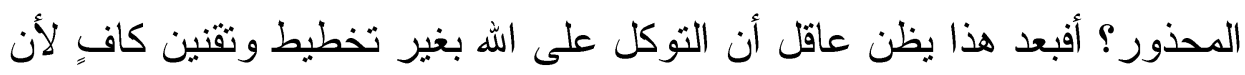

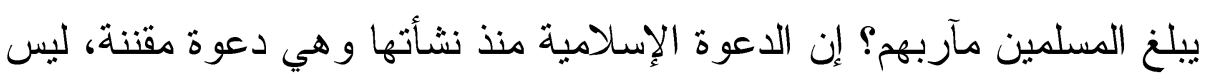

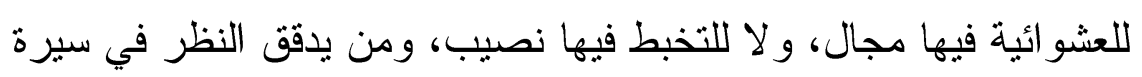

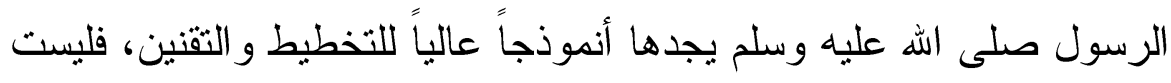
هناك خطوة من خطوات الدعوة غير مدروسة، وليس هناك عمل من الأعمال التي حققت هدفاً من أهداف الدعوة غير مخطط ولقد سارت الدعوة في مر احلها

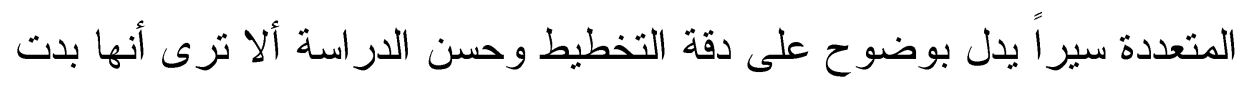

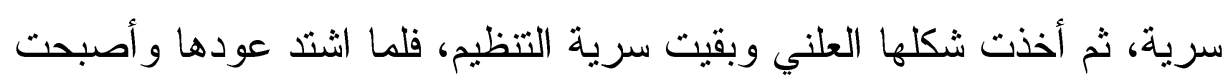
قادرة على المواجهة والصمود خرجت على الناس جميعاً بشكلها النهائي؟(19). 
المبحث الخامس

من نماذج الاعوة بيعة العقبة الأولى والثانية:

حيث ورد في هذا المبحث قول ابن إسحاق (خرج رسول الله صلى الله

عليه وسلم، في الموسم الذي لقي فيه النفر من الأنصار، فعرض نفسه على قبائل العرب، كما كان يصنع في كل موسم، فبينما هو عند العقبة لقيه رهطٌ من هن

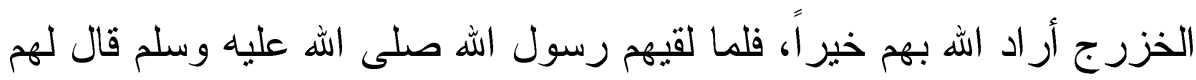
من أنتح؟ قالو ا: نفر من الخزرج، قال: أمن موالى يهود؟ قالو ا: نعم. قال أفلا

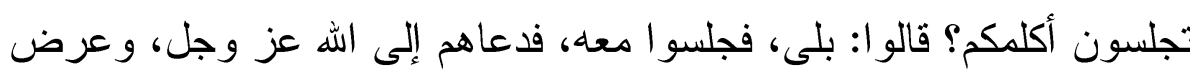
عليهح الإسلام، وتلا عليهم القرآن، قال وكان مما صنع الله بهم في الإسلام أن

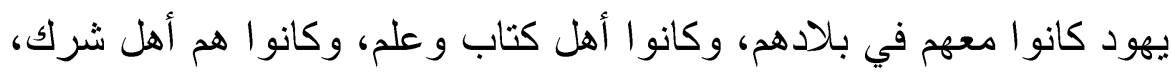

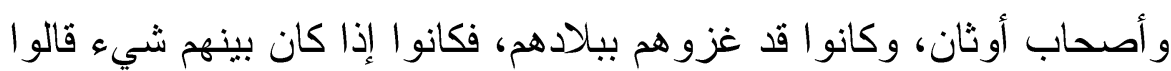
لهم: إن نبياً مبعوث قد أظل زمانه، نتبعه فنقتلكم معه، قتل عاد وأرم، فلما كلم رسول الله صلى الله عليه وسلم أولئك النفر، ودعاهم إلى الله قال بعضهم لبعض، يا قوم، تعلمون و الله أنه للنبي الذي توعدكم به يهود فلا تسبقنكم إليه، فأجابوه فيما دعاهم إليه، بأن صدقوه وقبلو امنه ما عرض عليهم من الإسلام، وقالوا إنا قد تركنا قومنا، و لا قوم بينهم من العداوة والشر ما بينهم فعسى أن يجمعهم الله بك، فسنقدم عليهم فندعو هم إلى أمرك، ونعرض عليهم الذي أجبناك إليه من هذا الدين، فإن يجمعهم الله عليه فلا رجل أعز منك. ثم انصرفو ا عن رسول الله صلى الله عليه وسلم راجعين إلى بلادهم، وقد آمنو اوصدقو او هم ستة نفر من الخزرج. فلما قدموا المدينة إلى قومهم، ذكروا لهم رسول الله صلى الله عليه وسلم، ودعو هم إلى الإسلام، حتى فشا فيهم، فلم يبق دار من دور الأنصار إلا وفيها ذكر من رسول الله صلى الله عليه 
حتى إذا كان العام المقبل و افى الموسم من الأنصار اثثا عشر رجلاً،

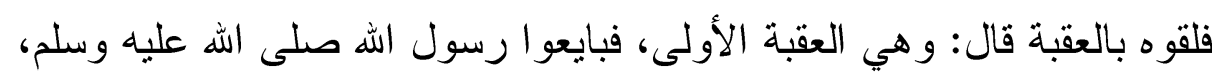

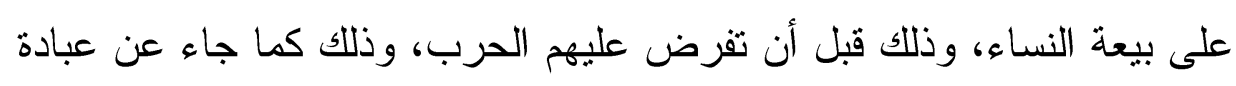

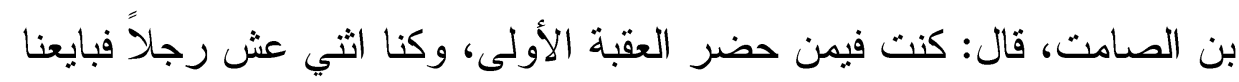

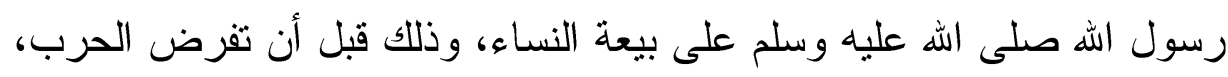

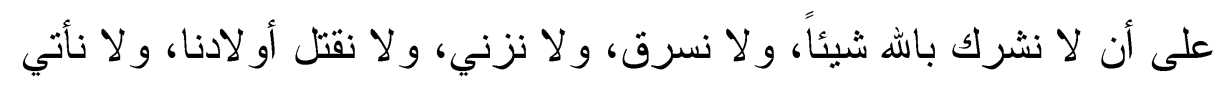

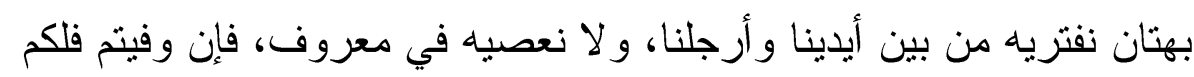

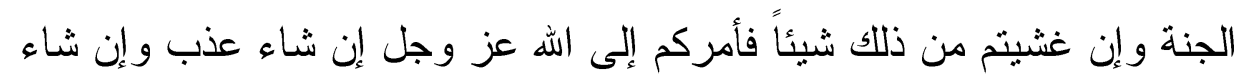
غفر.

وفي رو اية لعبادة بن الصامت قال: (بايعنا رسول اله صلى الله عليه

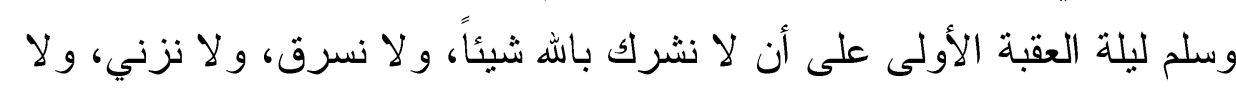

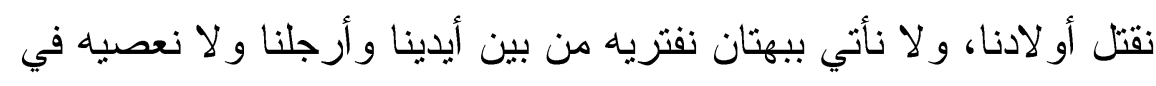

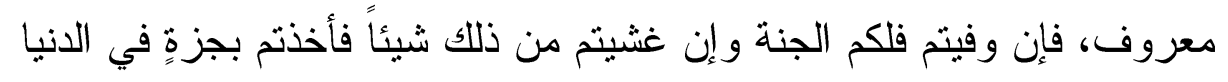

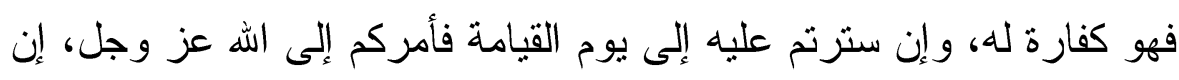
شاء عزب و إن شاء غفر)(20).

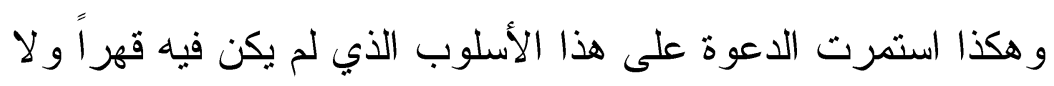

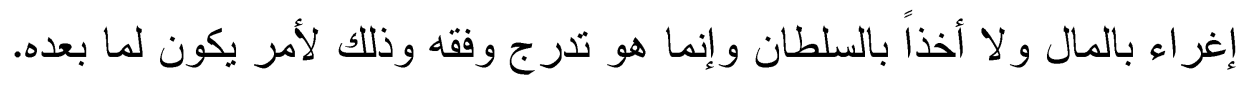

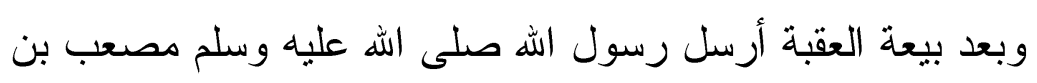
عمير رضي الله عنه إلى الددينة للاعوة إلى الله تعالى، ثم رجع إلى إلى مكة وخر اله

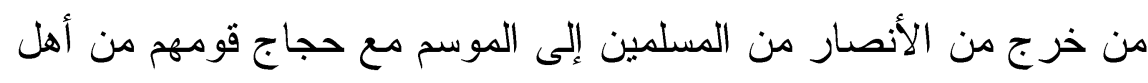

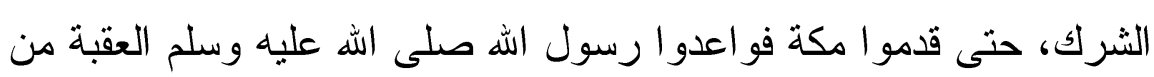
أوساط أيام التشريق، حيث أر اد الله بهم ما أر اد من كر امته، و النصر لنّا لنبيه و إعزاز الإسلام وأهله و إذلال الثرك و أهله. 
قال ابن إسحاق: حدثني معبد بن كعب أن أخاه عبد الله بن كعب ومان

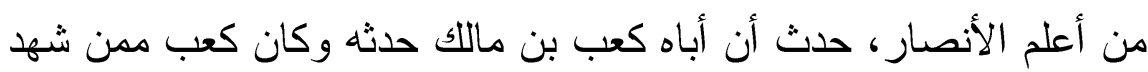

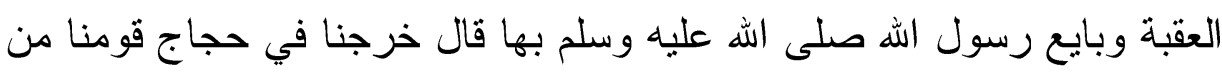
المشركين، وقد صلينا وفقهنا، ومعنا البراء بن معرور، سيدنا وكبيرنا فلما وجهنا

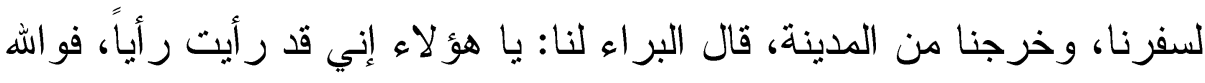

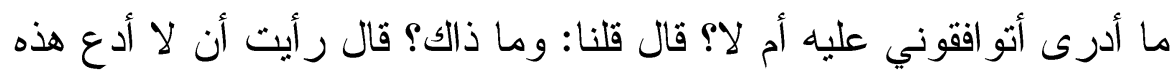

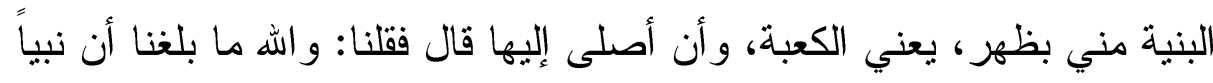

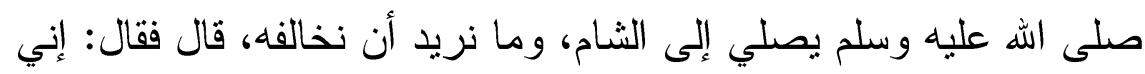

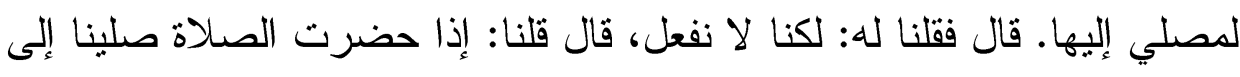

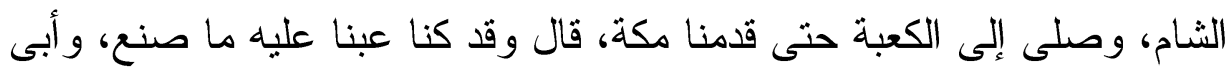

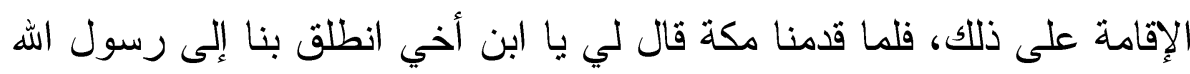

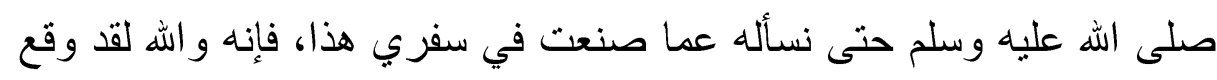

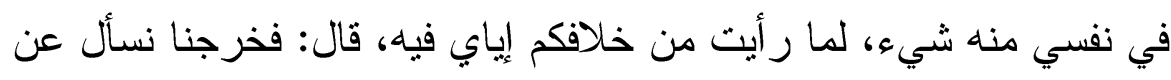

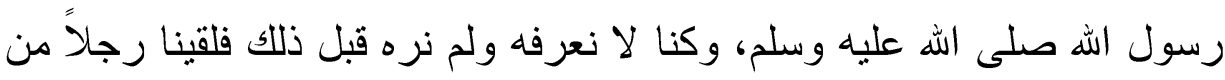
أهل مكة، فسألناه عن رسول اله صلى الله عليه وسلم فقال: هل تعرفانه؟ فقلنا:

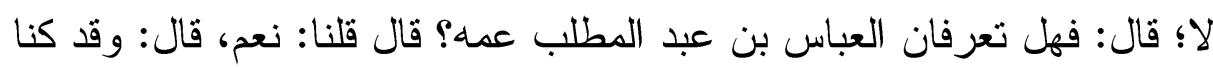

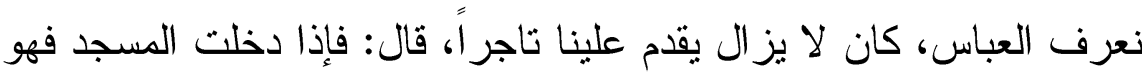

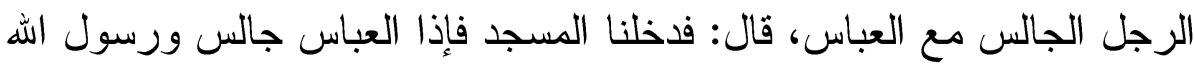
صلى الله عليه وسلم جالس معه، فسلمنا ثم جلسنا إليه، فقال رسول الله صلى الله

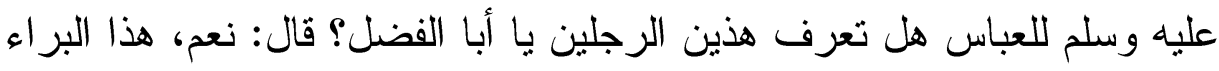

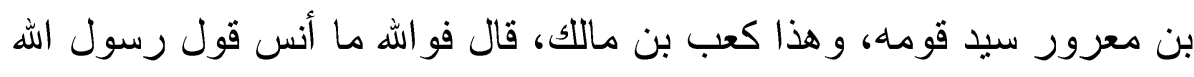

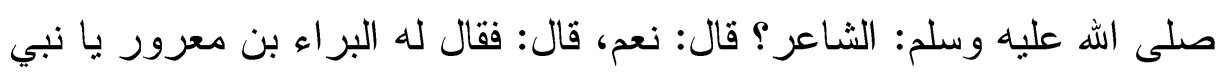

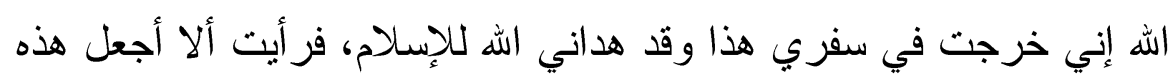

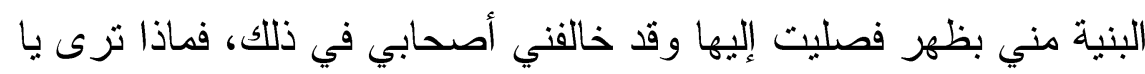


رسول الله قال: قد كنت على قبلة لو صبرت عليها، قال: فرجع البراء إلى قبل

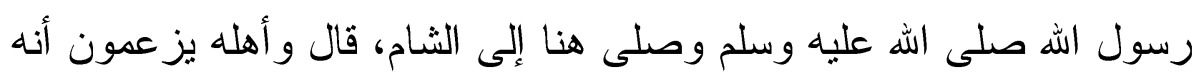
صلى إلى الكعبة حتى مات، وليس ذللك كما قالوا، نحن أعلم به منهم(21). من خلال هذا الحديث وفي عبارة (لو صبرت ولئ عليها) نرى فقهاً جميلاً

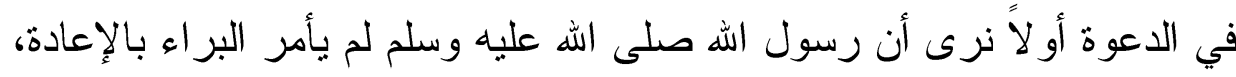

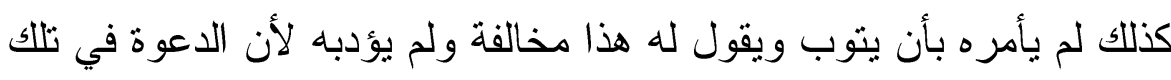
الفترة المكية تحتاج إلى تدرج مع المدعو وتحتاج إلى فقه يحل مشكلة الددعو.

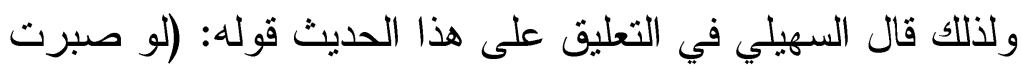
عليها) إنه لم يأمره بإعادة ما قد صلى لأنه كان مثأولاً.

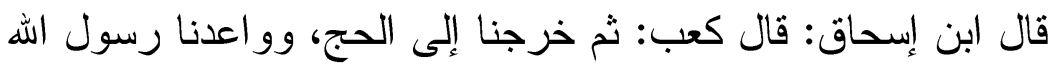

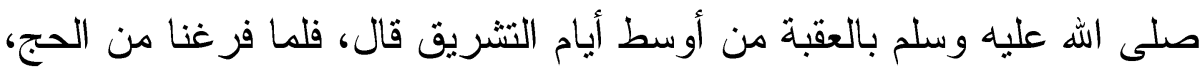

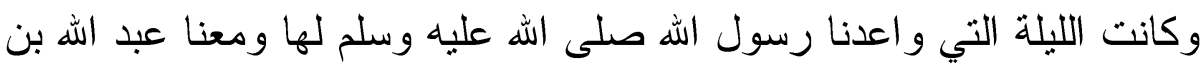
عمرو بن حرام ابن جابر سيد من ساداتتا وشريف من أثر افنا، أخذناه معنا، وكنا نكتم من معنا من قومنا من المشركين أمرنا.

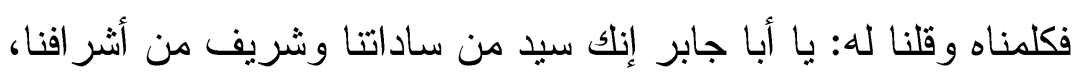
و إنا نرغب بك عما أنت فيه أن تكو حطباً للنار غداً، ثم دعوناه إلى الإسلام

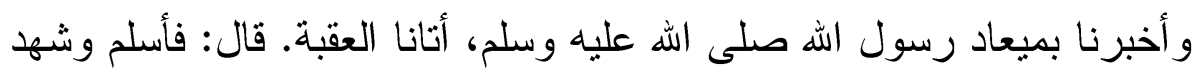

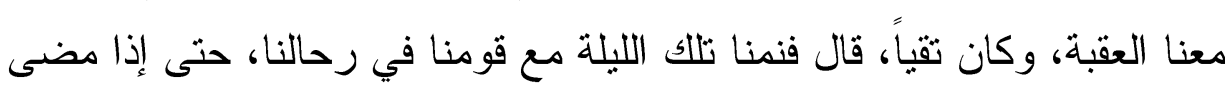

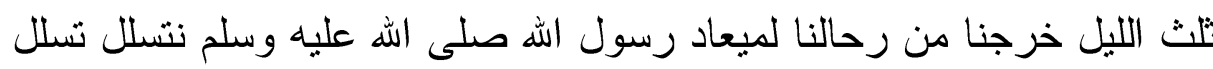
القطا مستخفين حتى اجتمعنا في الشعب عند العقبة، ونحن ثلاثة وسبعون رجلاً

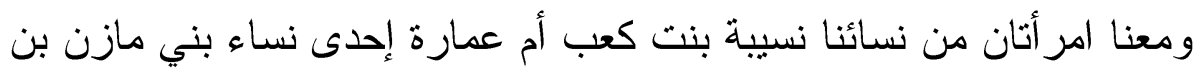

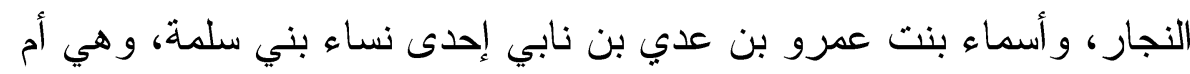
منيع(22). 
قال فاجتمعنا في الشعب ننتظر رسول الله صلى الله عليه وسلم حتى

جاءنا ومعه عمه العباس بن عبد المطلب، وهو يومئذٍ على دين قومه، إلا أنه

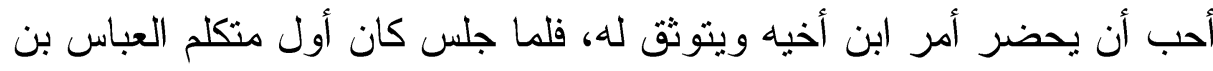
عبد المطلب فقال: يا معشر الخزرج، قال: وكانت العرب إنما يسمون هذا الحي

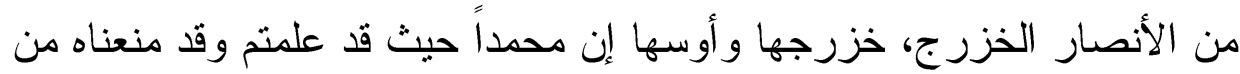

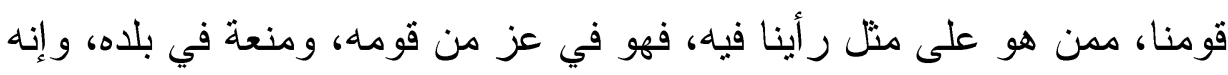

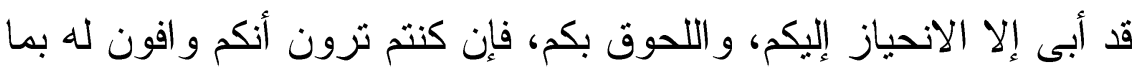

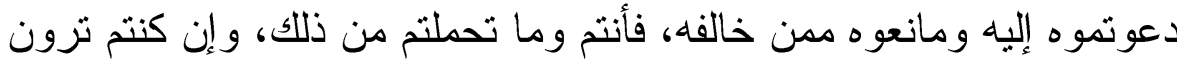

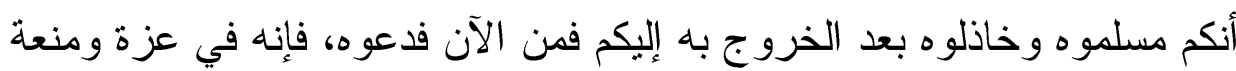
من قومه وبلده، قال فقلنا له: قد سمعنا ما قلت، فتلكم يا رسول اله فخذ لنفسك النك ولربك ما أحبيت. قال: فتنكلم رسول الله صلى اله عليه وسلم فتلا القر آن، ودعا إلى الله، ورغب في الإسلام، ثم قال أبايعكم على أن تمنعوني مما تمنعون منه نساءكم

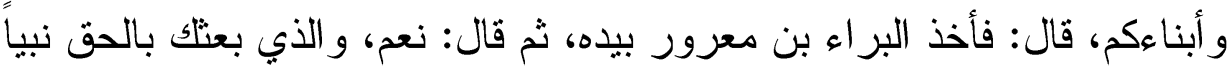

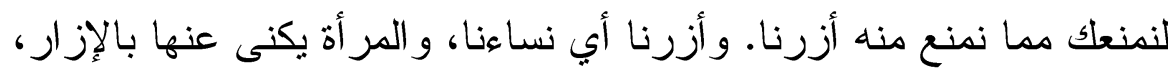

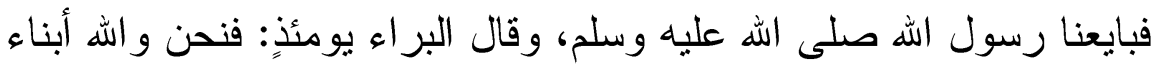

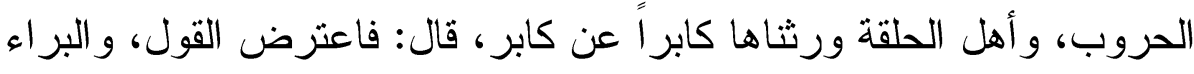

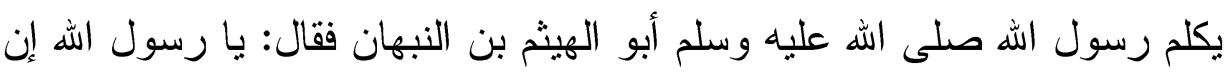

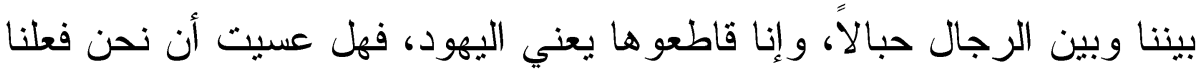

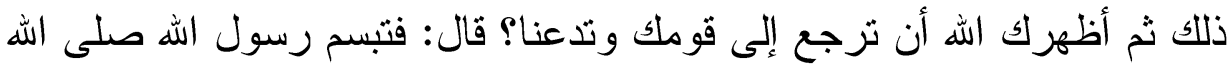

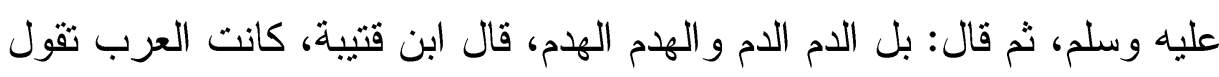

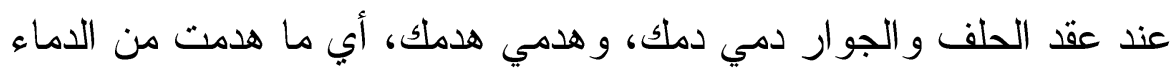

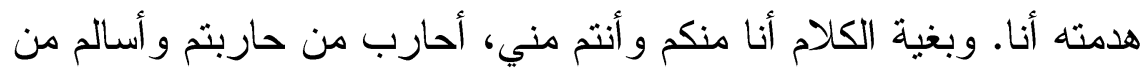

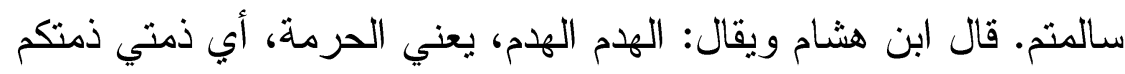
وحرمتي حرمنكم. 
قال كعب بن مالك: وقد كان قال الرسول صلى الله عليه وسلم أخرجوا

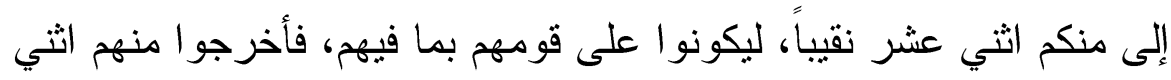
عشر نقيباً تسعة من الخزرج وثلاثة من الأوس.

قال ثم قال رسول الله صلى الله عليه وسلم: أرفضو الثنا إلى رحالكم، قال:

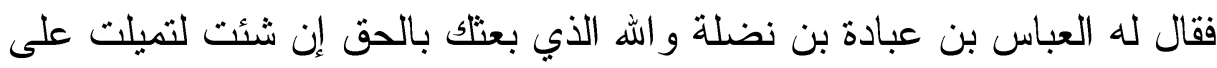

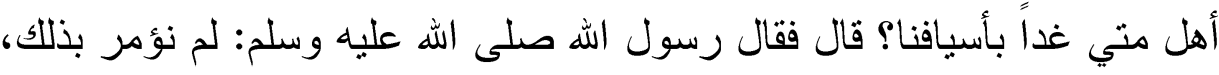
ولكن ارجعوا إلى رحالكم، قال: فرجعنا إلى مضاجعنا، فنمنا عليها حتى فلى لإلى

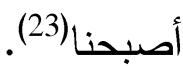

قال ونفر الناس من مينى فنتطس القوم الخبر فوجدوه قد كان، وخرجوا

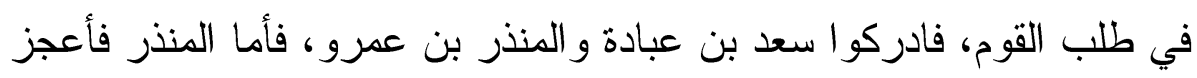

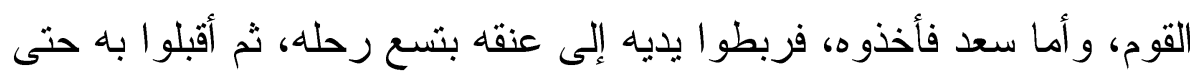

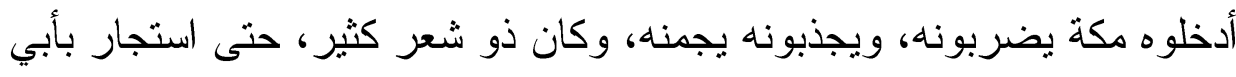

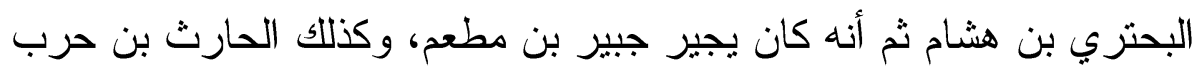
بن أمية)(24).

و إلى هنا بدأت حياة جديدة في الدعوة، بعد هذه البيعة، ومنهج جديد

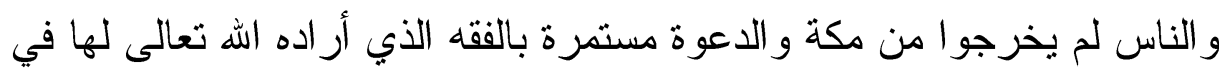

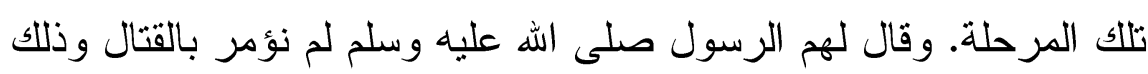

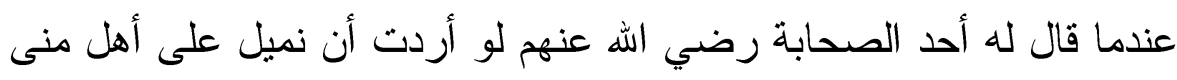

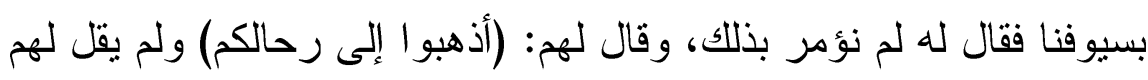

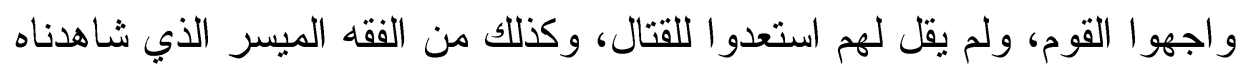

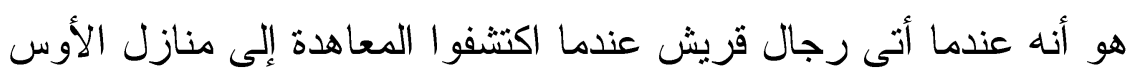

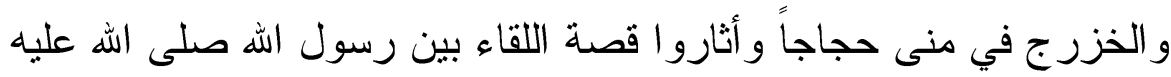

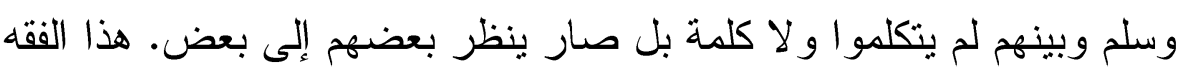

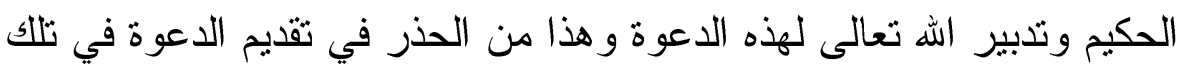


المبحث السادس

\section{مضمون الخطاب الاعوي}

في تلك الفترة المكية كانت البداية من عند رسول الله صلى الله عليه وسلم، وكان المضمون الدعوي هو أن يقرأ الإنسان وذلك كما جاء التوجيه إلى هي رسول الله صلى الله عليه وسلم، فقال له ربه (إقرأ) وكان القرآن الكريم هو المضمون في تلك وبدأ نزوله ورسول الله صلى الله عليه وسلم كان يملكه

للمدعويين، فكل آية تنزل كان الصحابة رضي الله عنهم يعرفون مقاصدها وبر اعتها ويعرفون ما ترمي إليه فهو في دار الأرقم يدرس هذا المضمون وكان التركيز في المنهج الدر اسي التقيفي يرتكز على تفهيم وتوطيد وشرح العقبدة الصحيحة في حق الله تعالى لأن الناس كانوا حديثي عهد بالإسلام. ثم كان شرح الصفات اللازمة والصحيحة في حق الله تعالى وتعليم أسمائه الحسنى، كما كان من مهامها التدريب على تلاوة القرآن الذي كان ينزل تباعاً كي يقرعونه بطريقة

صحيحة ثم يجملونه لمن خلفهم. ثم شرح بعض الأحكام القليلة التي ترد في القر آن ومعظمها كان في العقيدة والأخلاق، ثم فرضت الصلاة بعد ذلك بعض(25).

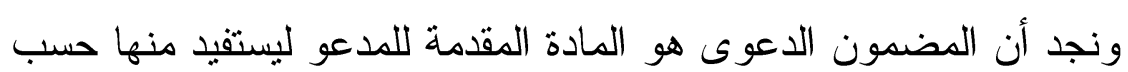
حاجته، وهي كذلك لا يمكن تجديدها لأنها تتتوع بحسب حاجة المدعو و المعرفة التي تتقصه، فقد يحتاج المدعو أن يعلمه الداعي سورة الفاتحة، فتكون هي المضدون المحمول إليه، وربما كان المضمون مدرسة أو مسجد يسد حاجة تتقص المدعو وهكذا يتتوع ويتعدد الموضوع المقدم المحمول بالوسيلة، و على العموم فإن موضوع الدعوة أو المضمون هو كل ما يصلح شأن وحال المدعو و لا يعارض المنهج الإسلامي العام. و أصول الدين ومقاصده فالإسلام كله مضمون دعوى وموضوع له وبالتالي نقول: أن مضمون تلك الفترة كان هو القرآن الكريم وما يأتي من تفسير وتعليم و إرشاد من الرسول صلى الله عليه وسلم. و عليه كان العمل، وكان فقه الدعوة من القرآن الكريم، حيث أخذ به وله 
الرسول صل الله عليه وسلم، وكانت به خطو اتهم في الدعوة، وكان منهجهم في

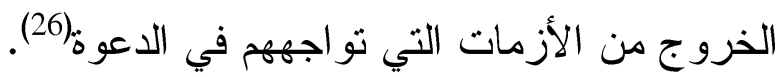
ولذلك لما بدأت الاضطهادات في السنة الرابعة من النبوة فئ، بدأت ضعيفة، ثم لم

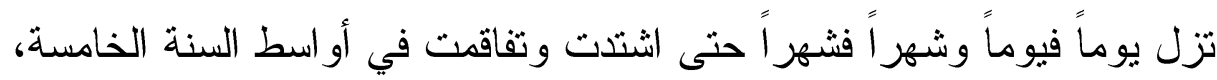

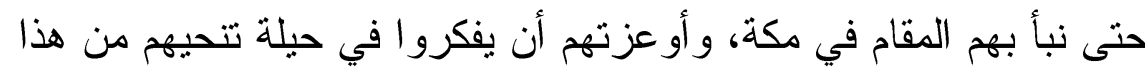

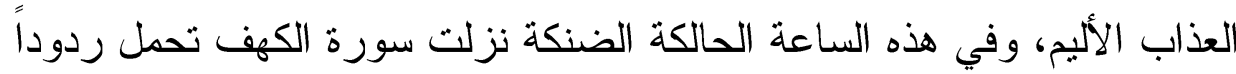

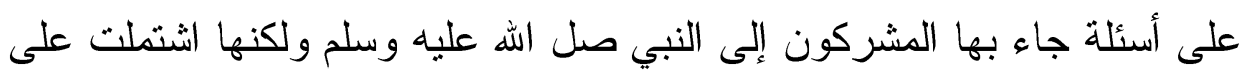
ثلاث قصص فيها إثار ات بليغة من الله تعالى إلى عباده المؤمنين، فقصة

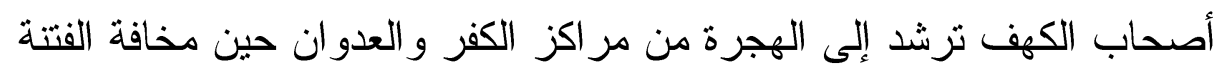

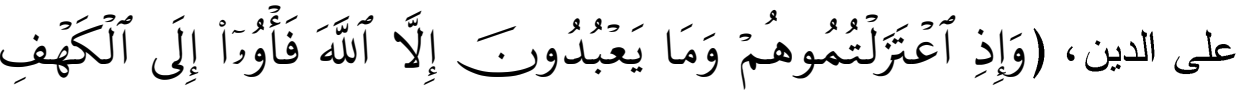

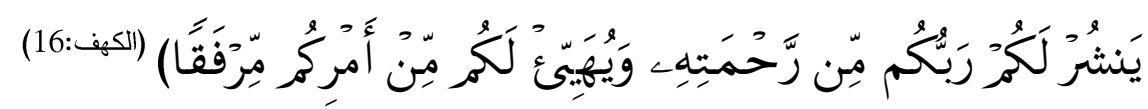
وقصة الخضر وموسى تقبد أن الظروف لا تجرى و لا تتتج حسب الظاهر دائماً،

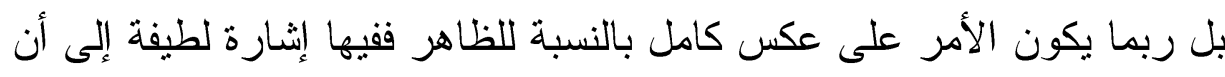
الحرب القائمة ضد المسلمين ستتكس تماماً وسيهزم هؤ لاء الطغاة المشركون إن بكأن لم يؤمنو ا أمام هؤلاء الضعفاء المدحورين من المسلمين، قال تعالى: ( أََّّا

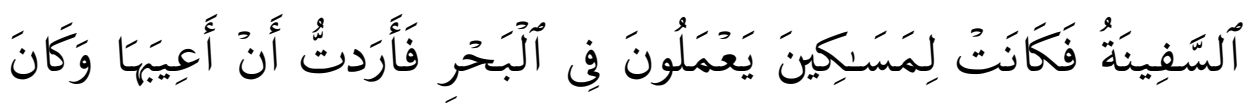

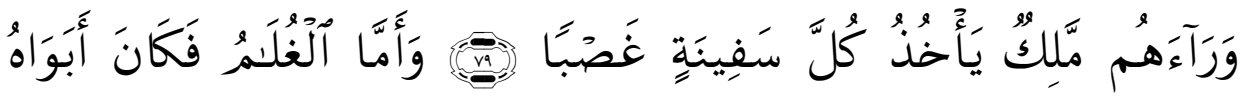

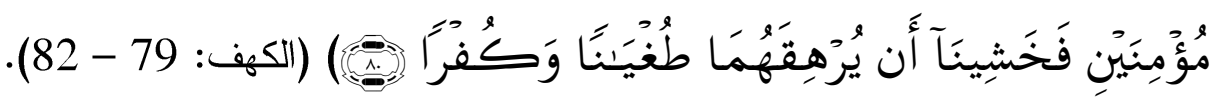
وقصة ذي القرنين تفيد أن الأرض لله يورثها من عباده من يشاء، وأن الفلاح

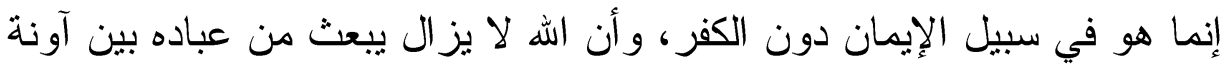

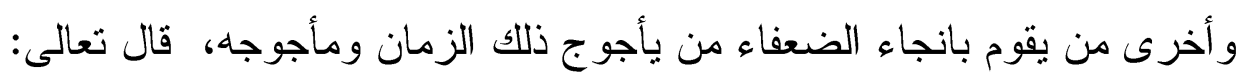




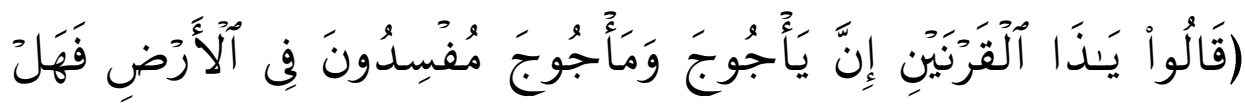

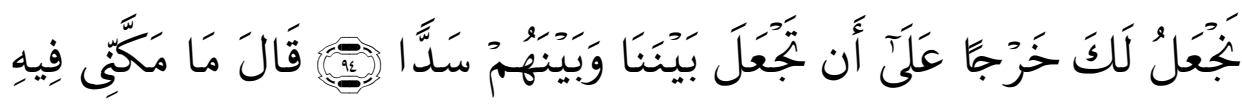

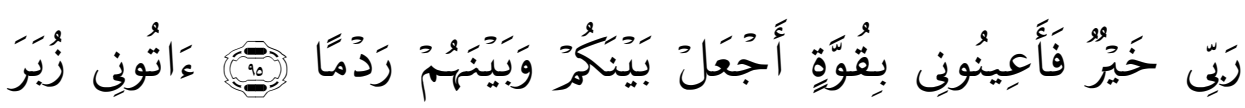

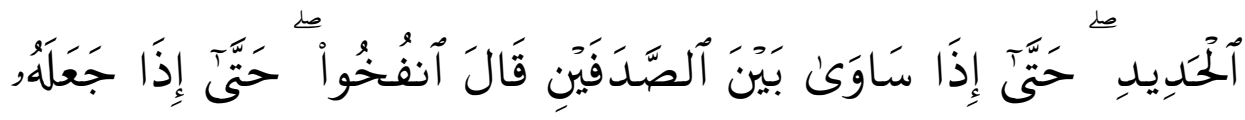

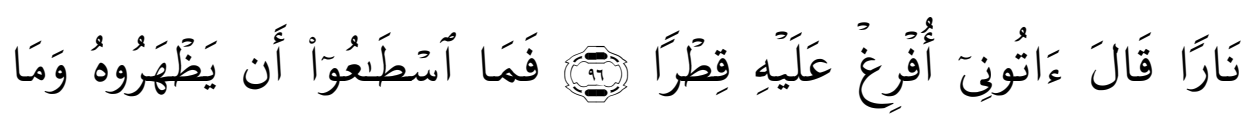

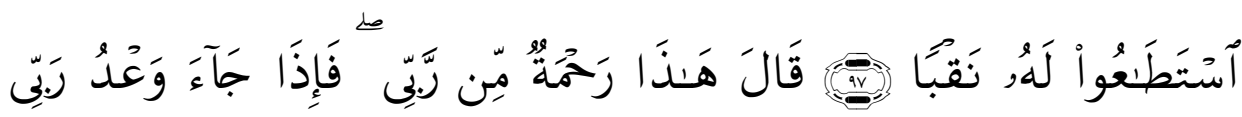

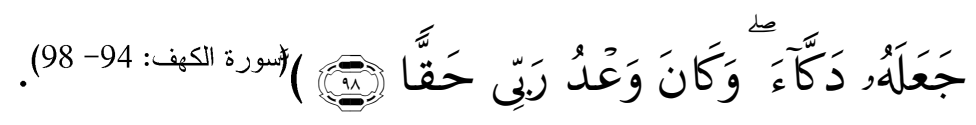

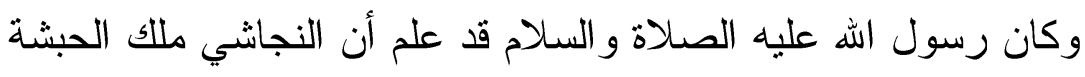

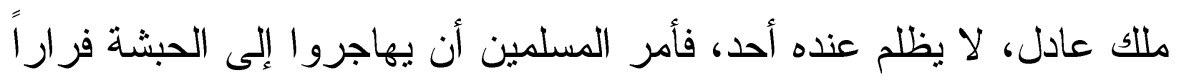

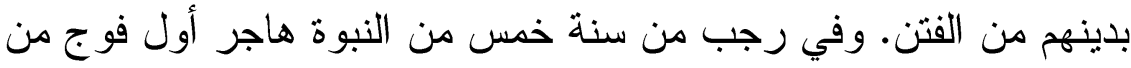

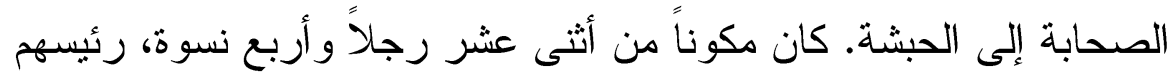

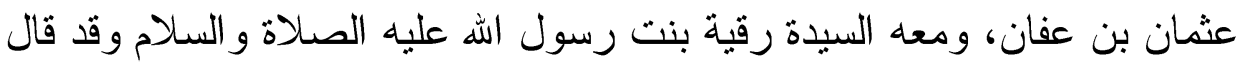

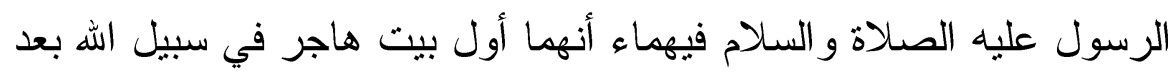
إبر اهيم ولوط عليهما السلام.

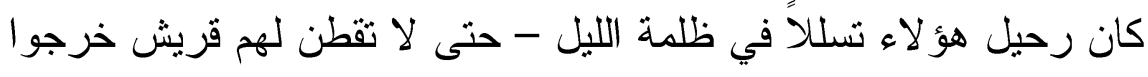

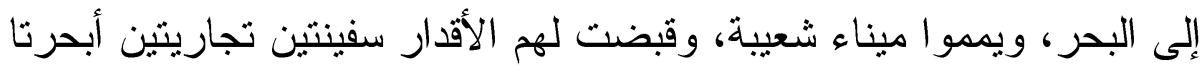

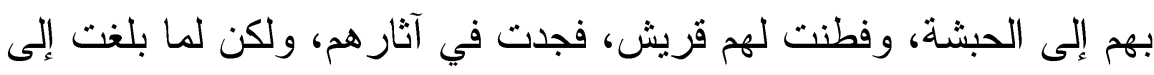

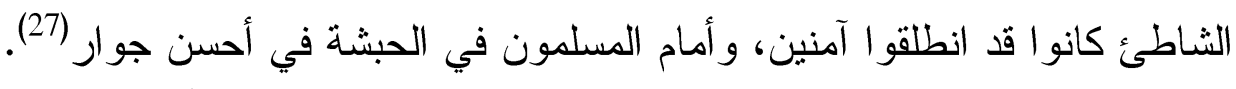

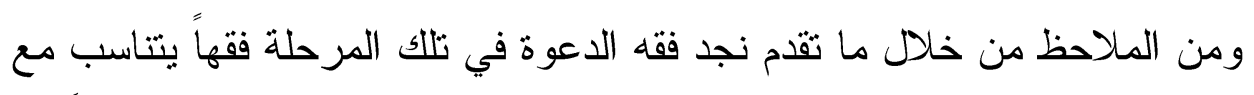

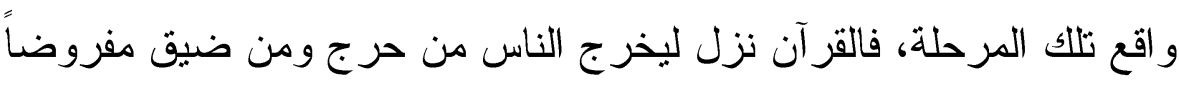


عليهم، حيث لم يتخذ رسول الله عليه الصلاة والسلام قراراً لبقول للجماعة أخرجو ا خارج مكة إلا بعد نزول القرآن الكريم، ثم كان من فقه الدعوة في تلك المرحلة خروج الصحابة رضي الله عنهم تسلاً في ظلمة الليل. حتى لا يقطن لهم أحد، ثم أن من فقه الدعوة في تلك المرحلة القرآن الكريم، وكان رسول الله عليه الصلاة و السلام في مكة، يقذف في قلوب قريش القرآن الكريم، كان يحرك قلوبهم، ويسحر هم بالقرآن حتى يصرع الحق عنادهم، وهم لا يشعرون. و هذا ما حدث في رمضان من أواخر السنة الر ابعة، خرج النبي عليه الصلاة و السلام إلى الحرم، وهناك جمع كبير من قريش، كان فيه سادتها وكبرؤها، فقام فيهم، و أخذ يتلو سورة النجم بغتة، وإن أولئك الكفار لم يكونوا سمعو اكلام الله قبل ذلك، لأن أسلوبهم المتو اصل كان هو العمل بما نو اصى به بعضهم بعضاً من

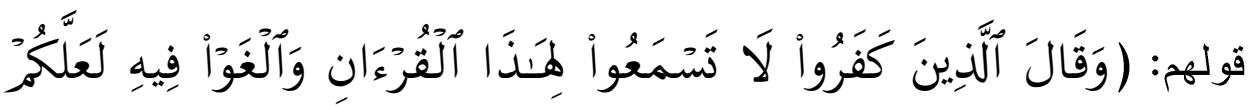

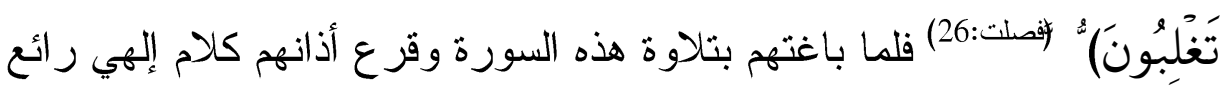
خلاب - لا يحيط بروعته وجلالته البيان - تفانو ا عما هم فيه، وبقي كل و احد مصغياً إليه، لا يخطر بباله شيء سو اه، حتى إذا تلا في خو اتيم هذه السورة

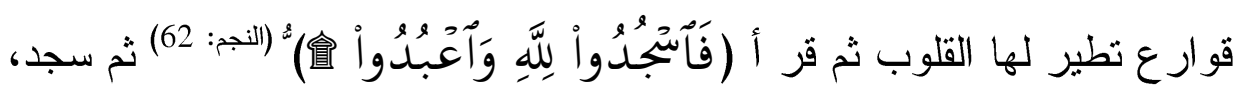
ثم لم يتمالك أحد نفسه حتى خر ساجداً، وفي الحقيقة كانت روعة الحق قد صدعت العتاد في نفوس المستكبرين و المستهزئين، فما تمالكو أن يخروا لله ساجدين)(28) فهذا هو المضمون الدعوي الذي كان عليه العمل في تلك المرحلة والذي أنمنى أن يكون عليه الدعاة وأسأل اله التوفيق . الخاتمة : الخماتح من خلال الدراسة والعرض توصل الباحث إلى عدد من النتائج الممنهة و التوصيات القابلة للتطبيق 
1. الدعوة في كل عصر وفي كل مصر تحتاج إلى فقه. 2. من أحسن الأساليب و الوسائل في الدعوة تلك الخطة التي وضعت فئ في لى فئه

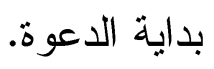
3. التدرج في الدعوة مع المدعويين أدى إلى إقلاع الناس عما ألفوه في

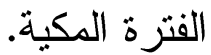
4. الحذر وأخذ الحيطة كان في بداية الدعوة أمراً ضرورياً. 5. متابعة المدعوين وتعهدهم بالتربية.

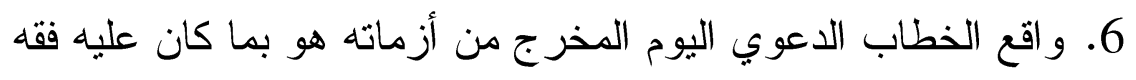

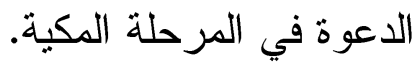

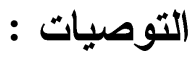
وبناءً على ما توصلت إليه من نتائج يوصى الباحث على ما يلي: 1. الفقه في الاعوة في كل عصر من عصور هنا. 2. لابد من الرجوع إلى التدرج القر آني الذي أخذ بالمدعوين شيئًا فشيئاً.

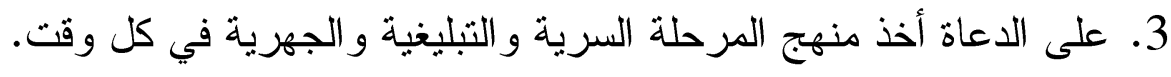
4. على الدعاة أخذ الناس بالقرآن وذللك كما كان في الفترة المكية. 5. تتوع أسلوب الداعية وذلك على حسب و اقع المكان و الزمان. 6. لابد من ربط الو اقع الدعوي الحالي بو اقع الماضي الدعوي.

\section{الهو امش :}

1. المدخل لعلم الدعوة، محمد أبو الفتح البيانوني.

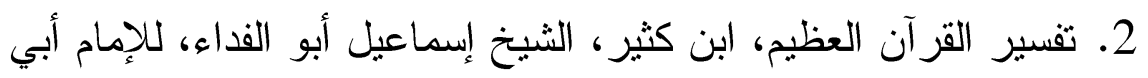

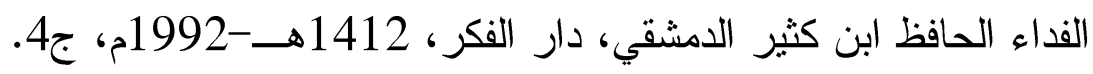


3. في ظلال القرآن، سيد قطب، دار الثروق، الطبعة الثانية، 1406 1986هـ

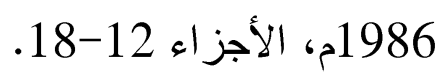

4. تقنين الدعوة، محمد السيد الوكيل.

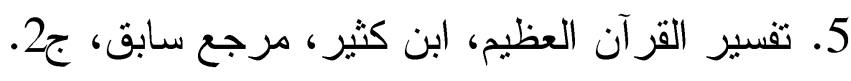

6. تقنين الدعوة، محمد السيد الوكيل، مرجع سابق.

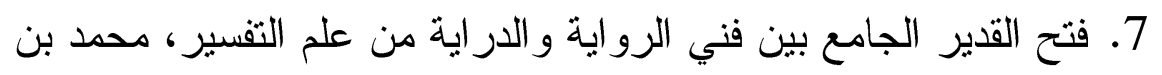

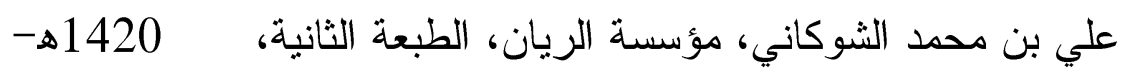

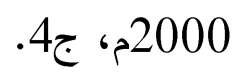

8. في ظلال القرآن، سيد قطب، مرجع سابق، الأجزاء 12-18.

9. تقنين الدعوة، محمد السيد الوكيل، مرجع سابق.

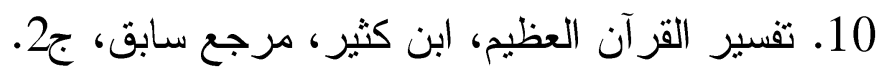

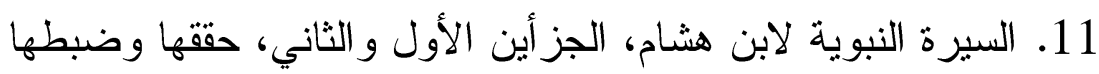

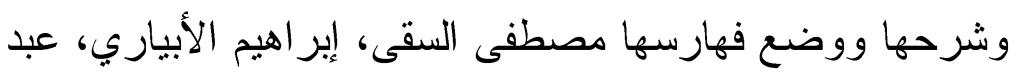

الحفيظ شلبي.

12. كتاب علي بن أبي طالب، تألبف: محمد رضا، دار الكتب العلمية،

$$
\text { بيروت. }
$$

13. صحيح البخاري بشرح الكرماني، ج 14 14، 1405هـــ1985م، دار

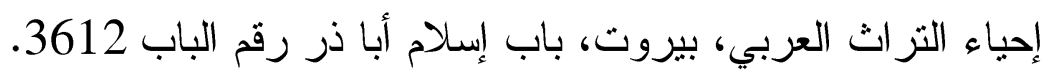

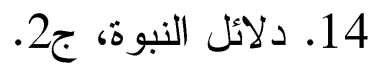

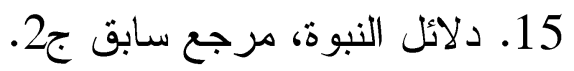

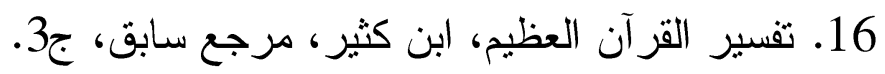

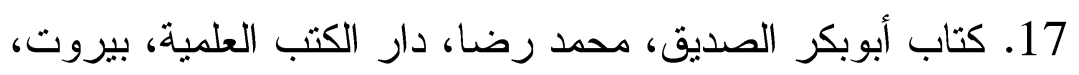

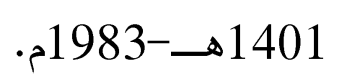

18. السيرة النبوية لابن هشام، مرجع سابق، ج1ام. 
19. تقنين الدعوة، محمد السيد الوكيل، مرجع سابق.

20. السيرة النبوية لابن هشام، مرجع سابق.

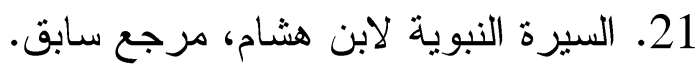

22. السيرة النبوية لابن هشام، مرجع سابق.

23. السيرة النبوية لابن هشام، مرجع سابق.

24. السيرة النبوية لابن هشام، مرجع سابق.

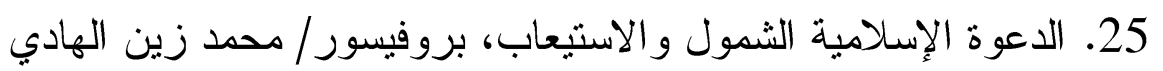

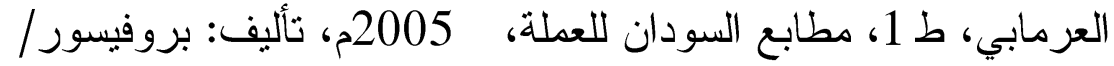

$$
\text { محمد زين الهادي العرمابي. }
$$

26. الدعوة الإسلامية الثمول والاستيعاب، بروفيسور / محمد زين الهادي

$$
\text { العرمابي، مرجع سابق. }
$$

27. الرحيق المختوم، صفي الرحمن المباركفوري، دار المؤبد، تاريخ الطبع

$$
\text { 1418هـ-1998م. }
$$

28. الرحيق المختوم، صفي الرحمن المباركفوري، مرجع سابق. 